\title{
O PARCELAMENTO DO SOLO PARA FINS URBANOS NO MUNICÍPIO DE SÃO ROQUE (SP) ANALISADO À LUZ DA LEGISLAÇĀO AMBIENTAL
}

JONAS MIRANDA CANO 


\section{RESUMO}

E ste estudo analisa a ocupação urbana do solo relacionando-a com a legislação de parcelamento do solo para fins urbanos e de proteção ambiental. As disposições legais foram espacializadas em quatro áreas amostrais de aproximadamente $4 \mathrm{~km}^{2}(2 \mathrm{~km} \times 2 \mathrm{~km})$ localizadas no município de São Roque (SP). As áreas foram selecionadas de modo a abranger diferentes estágios e padrões de ocupação urbana e diferentes contextos ambientais naturais, especialmente geomorfológicos e hidrográficos. Foram calculadas as áreas legalmente destinadas à proteção ambiental: margens e nascentes de corpos d'água, topos de morros e áreas comdeclividades acentuadas. Relacionaram-se esses valores com os limites mínimos exigidos por lei para áreas institucionais, incluindo áreas de recreio e lazer, e com densidades populacionais absolutas e relativas hipotéticas. Com base nos resultados obtidos, concluiu-se o seguinte: 1) a expansão urbana no município tem se processadoà revelia das condições previstas em lei, em especial da legislação ambiental; 2) a aplicação da lei produziria uma ocupação antrópica menos transformadora do ambiente e da paisagem, restando muitas áreas passiveis de parcelamento; 3) a distribuição dos usos seria baseada em critérios sócioeconômicos e ambientais, onde as próprias características ambientais já condicionariam os usos. Por fim, faz-se uma crítica à legislação quanto aos casos extremos, de difícil aplicação.

\section{ABSTRACT}

T his essay analyses urban settlements process relating it to the legislation of urban land plottings and of environmental protection. Legal dispositions were plotted in four sample areas with about $4 \mathrm{~km}^{2}(2 \mathrm{~km} \times 2 \mathrm{~km})$ located in São Roque(SP) municipal district. The areaswere selected in the way of comprising different stages and patterns of urban settlements and different natural environmental contexts, principally geomorphological and hidrographical ones. The areas legally destinated to environmental protection (borders and riverheads of bodies of water, mountain tops and high-declivity areas) were delimitated and size-calculated. These values were related to the minimum limits imposed by law for public spaces, including recreation and leisure areas, and to hypothetic absolute and relative population densities. Based on results, one concluded: 1) urban spreading in São Roque has being proceeding in absence of conditions due to the law, specially the environmental one; 2) putting the law into practice would create a less envorinment- and landscapechangeable human settlements, remaining many areas to be urban-plotted;3) land uses would be arranged based on social-economic and envirnmental criteria, wherein environment characteristcs themselves would regulate land uses distribution. Finally, it is made a comment upon legislation for the extreme situation, of difficult practice. 


\section{INTRODUÇÃO}

ara ser aprovado pelas autoridades competentes, um loteamento precisa apresentar uma série de informações bem como implementar uma quantidade mínima de infra-estrutura antes de ser comercializado. Machado (1989) ressalta que "a aprovação ou o indeferimento do projeto de loteamento é de natureza vinculada", pois a lei prevê um conjunto de restrições quando usa a expressão "não será permitido o parcelamento" Além disso, deve seguir algumas restrições legais do ponto de vista ambiental. Essas restrições referem-se a áreas com determinadas características que visam proteger o ambiente contra poluição, processos geomorfológicos indesejáveis, entre outros, bem como resguardar processos ecológicos essenciais à vida, como recarga de aqüíferos, regulação microclimática, etc.

Diversas são as áreas previstas pela legislação impedidas ao uso e ocupação antrópicos. No âmbito federal, duas leis destacamse como as que mais restringem o uso e a ocupação do solo:

a) Lei n. 4.771, de 15/09/1965, que institui o novo Código Florestal, cujo texto foi posteriormente revisto e alterado, tornando-se mais restritivo e abrangente, pelas leis n. 6.535, de 15/ 06/78, n. 7.511, de 07/07/86, e n. 7.803, de 18/07/89;

b) Lei n. 6.766 , de 19/12/79, que dispõe sobre o parcelamento do solo urbano.

Um outro diploma legal federal importante é a Resolução CONAMA n. 4/85 que define territorialmente as "Reservas Ecológicas" mencionadas no artigo 18 da Lei n. 6.938/81, bem como as estabelecidas pelo poder público de acordo com o que preceitua o artigo 1ำ do Decreto n. 89.336/84".

No âmbito estadual, há as restrições definidas pela Constituição Estadual de 1989, que em seus artigos 196 e 197 define genericamente as áreas no Estado de São Paulo que se constituem de "espaços territoriais especialmente protegidos" e "áreas de 
proteção permanente", respectivamente. As áreas são qualificadas, porém, não quantificadas territorialmente.

Na esfera municipal, a Lei Orgânica do Município de São Roque prevê em seu artigo 279 algumas áreas dentro de seu território consideradas "derelevante interesseparafins de proteção ambiental, sendo sua utilização condicionada à prévia autorização dosórgãos competentes, preservando seus atributos essenciais" São citadas algumas áreas, porém sem ter seus limites legalmente definidos.

Além destes, outros diplomas legais trazem em seus textos algumas restrições, especialmente às formas de uso, como o Código de Águas (Decreto federal n. 24.643/34), o Código de Minas (Decreto-Lei n. 227/67), a lei n. 6.803/80, sobre o zoneamento industrial em áreas críticas de poluição, entre outros.

Embora não especifique áreas destinadas à proteção ambiental, exceto as citadas genericamente no artigo $225, \S 4^{\circ}$, como patrimônio nacional (Floresta Amazônica brasileira, Mata Atlântica, Serra do Mar, Pantanal Mato-Grossense e Zona Costeira), a Constituição Federal de 1988 estabelece no $\S 1^{\circ}$, inciso VII, deste mesmo artigo, que, entre outras coisas, cabe ao poder público "definir, em todas as unidades da Federação, espaços territoriais e seus componentes a serem especialmente protegidos, sendo a alteração e a supressão permitidas somente através de lei, vedada qualquer utilização que comprometa a integridade dos atributos que justifiquem sua proteção"

É compreensível que as constituições, federal e estadual, e a lei orgânica do município somente qualifiquem "espaços territoriais especialmente protegidos" e "áreas de proteção permanente" e afins; o objetivo maior destes dispositivos é dar diretrizes gerais e não detalhar normas e condutas e, no caso, limites espaciais, que são objeto de legislação ordinária.

\section{OBJETIVOS}

Este trabalho visa avaliar dois pontos da relação uso do solo $x$ legislação: 
- a implantação dos parcelamentos em relação à legislação específica e ambiental;

- e a distribuição do uso do solo aplicando-se a lei.

\section{MATERIAL E TÉCNICAS}

Este trabalho baseou-se na legislação ambiental e de parcelamento do solo citada na bibliografia.

Para efetuar-se a espacialização cartográfica da legislação foram escolhidas quatro áreas amostrais (Figura 1). As amostras possuem uma área de aproximadamente $4 \mathrm{~km}^{2}(2 \mathrm{~km} \times 2 \mathrm{~km})$.

Fig. 1 Municipio de São Roque (SP), apresentando os limites da bacia hidrografica em estudo, a distribuição das áreas amostraise asprincipais áreas urbanas, 1995.

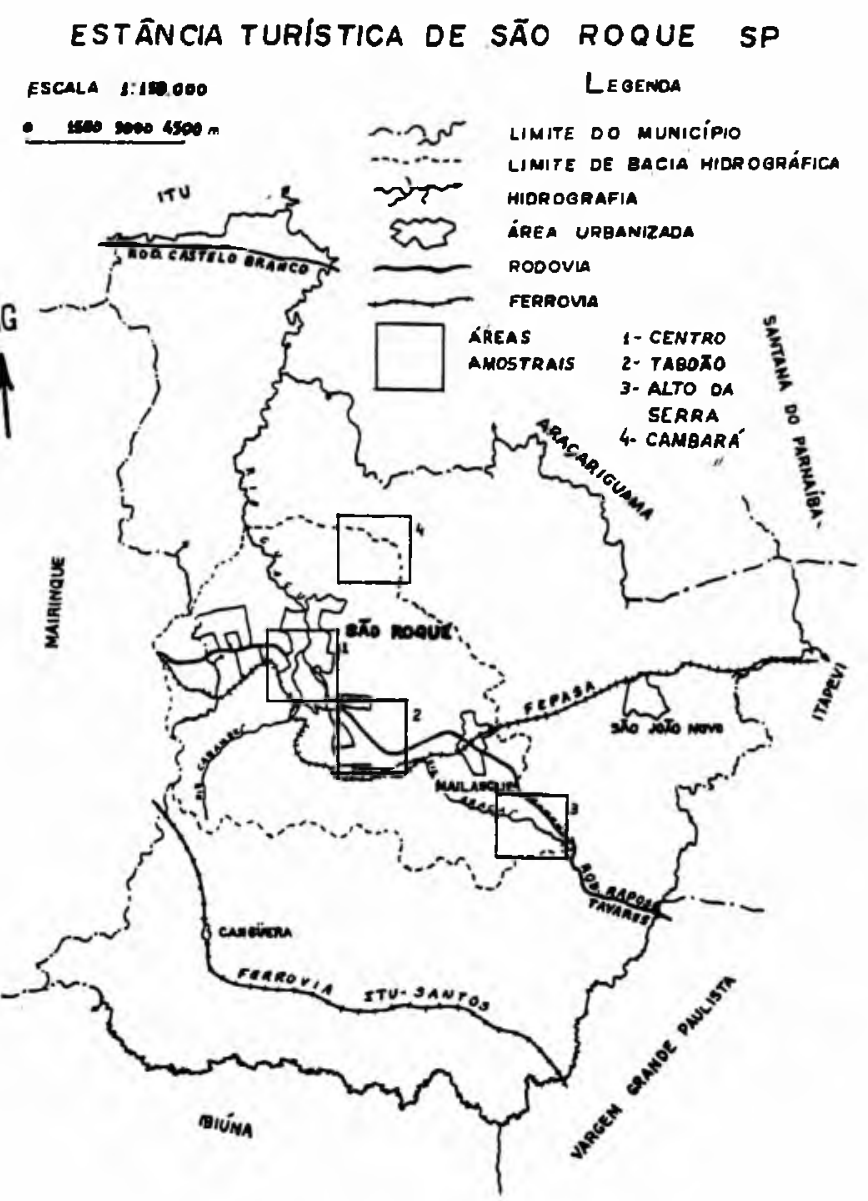


Os critérios de escolha das áreas foram a abrangência de:

- áreas de ocupação recente e antiga;

- parcelamento para chácaras e para alta densidade (inclusive conjuntos habitacionais), com diferentes densidades populacionais;

- e diferentes formas de relevo.

Foram utilizadas bases cartográficas do IGC (1979), escala 1:10.000, atualizadas pelos mapas cadastrais da prefeitura (escalas 1:500, 1:1.000 e 1:2.000).

Foram cartografados:

- Sistema viário;

- linhas de nível com equidistância de 25 m e pontos cotados;

- hidrografia;

- sistema de recreio (espaços livres de uso público);

- faixas marginais de $\mathbf{3 0} \mathrm{m}$ de cada lado ao longo dos corpos d'água;

- raio de $50 \mathrm{~m}$ junto às nascentes;

- intervalos de declividade (baseados nos valores referidos pela legislação. Tabela 1);

- linhas de cumeada e topos de elevações do relevo.

Tabela 1 - Restrições legais em função da declividade dada em ângulo e em porcentagem.

\begin{tabular}{|c|c|l|l|}
\hline Ângulo & Porcentagem & Definição legal & Dispositivo legal \\
\hline 0 a 1642' & $0 \%$ a 30\% & Parcelamento livre & \\
\hline 1642 ' a 25 & $30 \%$ a 46,6\% & $\begin{array}{l}\text { Loteamento somente } \\
\text { com prévia anuência } \\
\text { pública }\end{array}$ & Lei 6.766/79; art. 3º \\
\hline 25 a 45 & $\begin{array}{c}46,6 \% \text { a } \\
100 \%\end{array}$ & $\begin{array}{l}\text { Parcelamento } \\
\text { proibido; permitido } \\
\text { somente extração } \\
\text { racional de toros }\end{array}$ & $\begin{array}{l}\text { Código Florestal; } \\
\text { art. 10 }\end{array}$ \\
\hline $\begin{array}{c}\text { Acima de } \\
45\end{array}$ & $\begin{array}{c}\text { Acima de } \\
100 \%\end{array}$ & $\begin{array}{l}\text { Parcelamento } \\
\text { proibido; preservação } \\
\text { permanente }\end{array}$ & $\begin{array}{l}\text { Código Florestal, art. } \\
2^{\circ} \text { Resolução Conama } \\
\text { n. 4/85, art. 3o }\end{array}$ \\
\hline
\end{tabular}


As áreas dos espaços ocupados com cada preceito legal foram mensuradas utilizando-se a técnica do papel vegetal milimetrado. No caso das áreas das nascentes utilizou-se a fórmula de cálculo de área do círculo $\left(r^{2}\right)$. A área total de preservação permanente foi calculada somando-se as áreas de cada item. Não foi considerada a sobreposição das restrições por haver submensuração em alguns casos (como declividade) e devido à pouca precisão da técnica de mensuração utilizada. Para facilidade dos cálculos, os resultados foram arredondados para cima.

Com base nos mapas foram calculados os valores referentes a áreas de preservação permanente previstas em lei, áreas parceláveis, áreas públicas resultantes da porcentagem (35\%) sobre as áreas parceláveis exigidas em lei e sistema de recreio (10\% sobre a área parcelada). A partir desses dados foram feitas extrapolações quanto a possíveis densidades populacionais com três tamanhos hipotéticos de lote (250, 500 e $\left.1.000 \mathrm{~m}^{2}\right)$, isoladamente ou em conjunto e quanto a índices de áreas livres de uso público.

\section{CARACTERIZAÇÃO SUCINTA DO MUNICÍPIO}

O município de São Roque, cuja sede foi fundada em meados do século 17 (oficialmente em 16 de agosto de 1657) pelo capitão Pedro Vaz de Barros, localiza-se a aproximadamente 60 $\mathrm{km}$ a oeste da capital, ocupando atualmente uma área de 313 $\mathrm{km}^{2}$, entre as coordenadas $23^{\circ} 39^{\prime} 41^{\prime \prime} \mathrm{S}$ e $47^{\circ} 12^{\prime} 31^{\prime \prime} \mathrm{W}$. Situase na zona fisiográfica industrial do Estado. Limita-se ao sul com Ibiúna e Cotia, a leste com Vargem Grande Paulista e Itapevi, ao norte com Itu, Araçariguama e Santana do Parnaíba, e a oeste com Mairinque. É servido por duas rodovias, Castelo Branco e Raposo Tavares, e por duas ferrovias, a Itu-Santos e a Fepasa (Figura 2).

Segundo a classificação de Köppen, o clima é do tipo Cfa (mesotérmico úmido, sem estação seca, com verão quente) na porção centro-norte, e do tipo $\mathrm{Cfb}$ (mesotérmico úmido, sem estação seca, com verão fresco) na porção sul (Setzer, 1966). As 


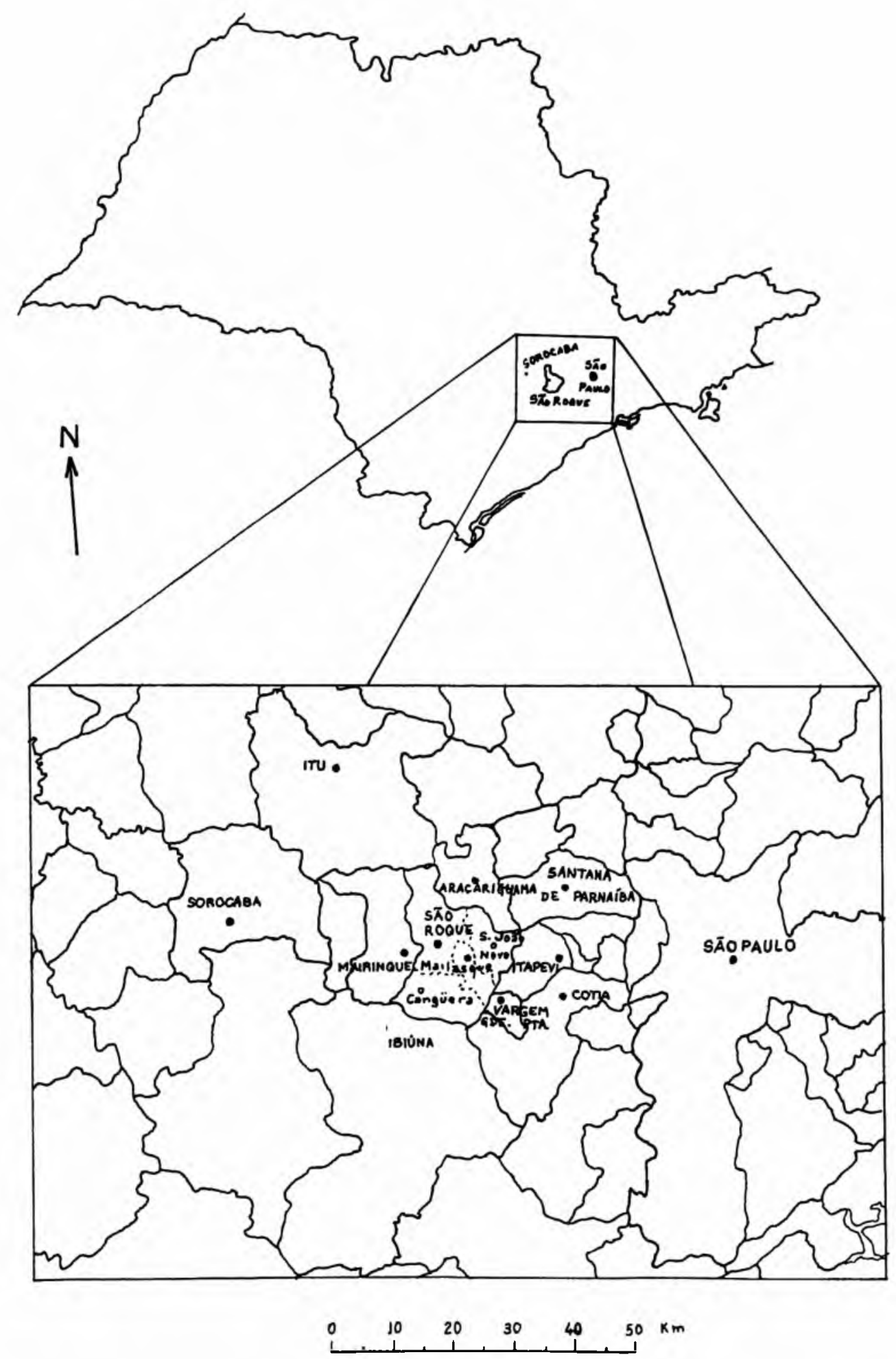

Fig. 2 - Município de São Roque, área atual (1995), suas divisôes administrativas, municípios limitrofes e situação quanto à sede administrativa regional. Sorocaba, a capital, São Paulo, e as sua antiga sede administrativa Santana do Parnafba. (1:1.000.000 - I.C.C.), 1984). 
temperaturas médias são: das máximas $30,2^{\circ} \mathrm{C}$, das mínimas $8,2^{\circ} \mathrm{C}$ e as anuais $19,8^{\circ} \mathrm{C}$ (Samartini, 1958). A pluviosidade média anual é de $1.322 \mathrm{~mm}$, com $228 \mathrm{~mm}$ de média para o mês mais chuvoso (janeiro) e $33 \mathrm{~mm}$ de média para o mês mais seco (agosto) (São Paulo, 1972).

De acordo com o mapa geológico do Estado de São Paulo (São Paulo,1981a) são três as unidades geológicas que ocorrem no município: Fácies Cantareira, Grupo São Roque (Hasui et al., 1969) e Grupo Açungui (Marini et al., 1958). Todas pertencem ao complexo cristalino e formaram-se no proterozóico superior entre 1 bilhão e 570 milhões de anos, salvo os sedimentos aluvionares que recobrem o fundo dos principais vales, formados durante o período quaternário há aproximadamente 10.000 anos.

O mapa geomorfológico do Estado de São Paulo (São Paulo, 1981b) mostra que o município situa-se na província do Planalto Atlântico, dentro da zona denominada Serrania de São Roque e, em menor parte, da zona denominada Planalto de Ibiúna, ao sul. Predomina um relevo acidentado, com morrotes, morros e serras entremeados por algumas planícies aluvionares.

Predominam solos latossólicos com alguns podzólicos e mais restritamente solos hidromórficos relacionados aos fundos de vale. (Centro Nacional de Ensino e Pesquisas Agronômicas, 1960.)

O municípioédrenado por duas importantes bacias hidrográficas: a do Médio Tietê, ao norte, e a do Sorocaba, ao sul. A drenagem é de alta densidade distribuída por todo o seu território.

A vegetação que ocorria no município era predominantemente de Mata Atlântica, representada pela Floresta Latifoliada Tropical de Encosta, bastante úmida, com muitos cipós, samambaias, orquídeas e árvores de grande porte como o jacarandá, e pela Floresta Latifoliada Tropical de Planalto, menos úmida, mas apresentando árvores de grande porte como peroba, cedro, paud'alho, figueira branca, canela, aroeira e ipê. Por entre estas 
matas, nas áreas de solos pouco férteis, mais rasos e pedregosos, principalmente em planaltos com muita incidência de ventos, interpunham-se campos sujos (Serrano, 1986). Embora tenha sido bastante devastada e ocorra basicamente em estrutura secundária, a vegetação nativa ainda cobre várias áreas espalhadas por todo o município, possivelmente em virtude do relevo acidentado que dificulta a exploração agrícola intensiva, principalmente a mecanizada (IGC, 1981) (Figura 3).

São Roque desenvolveu-se a partir do núcleo central sem qualquer planejamento, com ruas e calçadas estreitas, comuns em cidades antigas. A cidade foi crescendo lentamente até que, a partir da década de 50, com a implantação de diversas indústrias, começa a apresentar uma maior expansão com novos loteamentos. Nessa década os novos loteamentos situam-se principalmente nas imediações do núcleo central. Já a partir da década de 60, ocupavam tanto áreas adjacentes aos já existentes como áreas mais distantes junto às principais vias de acesso, em todos os sentidos. A década de 70 também é marcada por vários loteamentos que são instalados mais nos setores norte, oeste e sul. Para a década de 80 , é lançado um número menor de loteamentos, mais espalhados, sendo implantados especialmente no sul e norte. Nos últimos anos, vêm sendo abertos diversos loteamentos de chácaras residenciais ou de recreio destinadas basicamente a pessoas de média a alta renda da capital (Canno, 1989).

De um modo geral, a cidade não forma uma malha contínua, possivelmente em função da irregularidade do terreno, embora alguns loteamentos situem-se em áreas bastante declivosas (Canno, op. cit.) (Figura 4). 


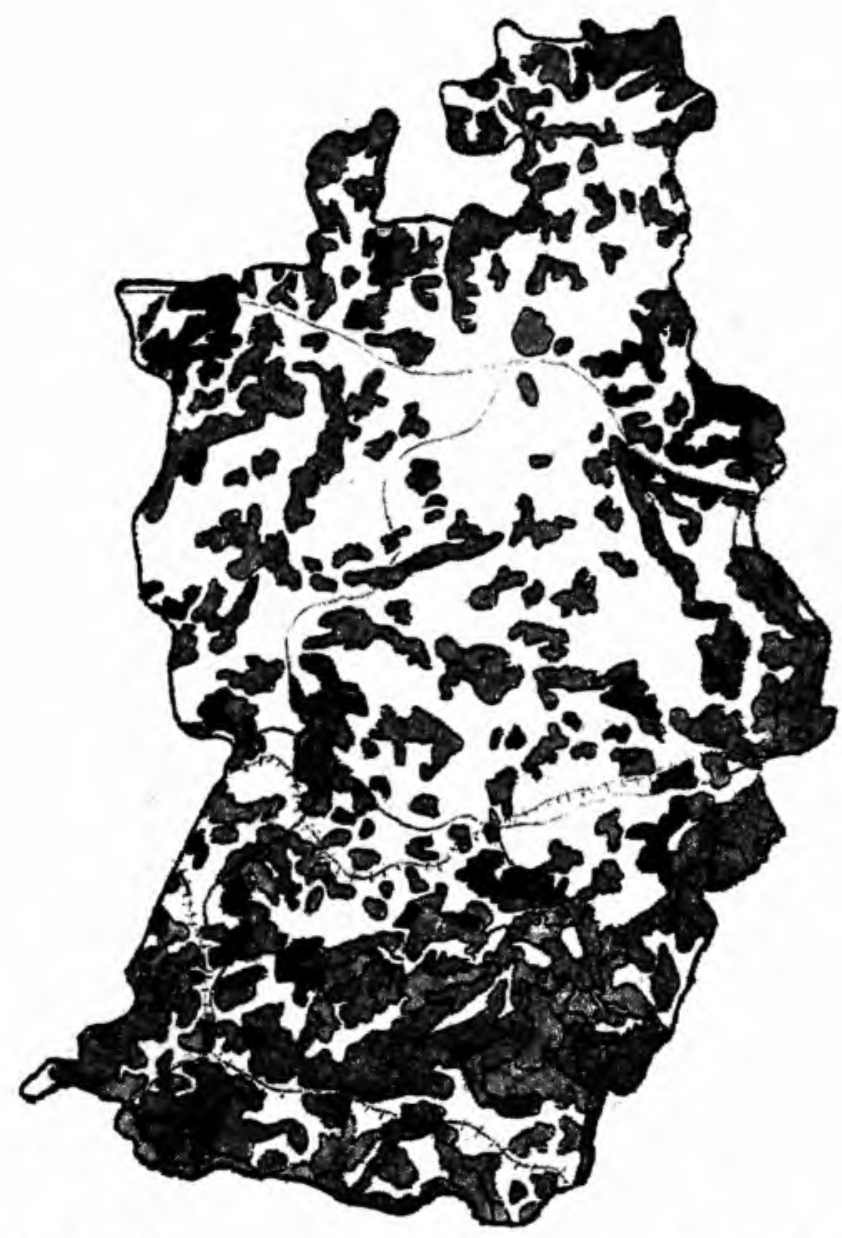

Utilizaçăo Agricola

Hortifrutigranjeiros

Café

Fruticultura

Cana-de-acucicar

Culturas Anuais

T. Fastagens e.ou Campo Antrópico

Silvicultura
Utilização Năo Agricola

Dárea urbänizada

Area Tnstitucional

Dukros Usus

Cobertura Vegetal Natural

\section{Florest}

Capoeila

97 Veg de Virzea e Banhartos

Fig. 3 - Diferentes usos do solo do munić́pio de São Roque-SP e suas distribuições (Carta de Utilização da Terra do Estado de São Paulo - 1:250.000 - IGC, 1981). (Obs.: Inclui o atual município de Araçariguama). 


\section{SĀO ROQUE - SP}

ESC. A DROX. 1:150.000
EXPANSAOO URBANA

LOTEAMENTOS

o

$1900 \quad 9000 \quad 4500 \mathrm{~m}$

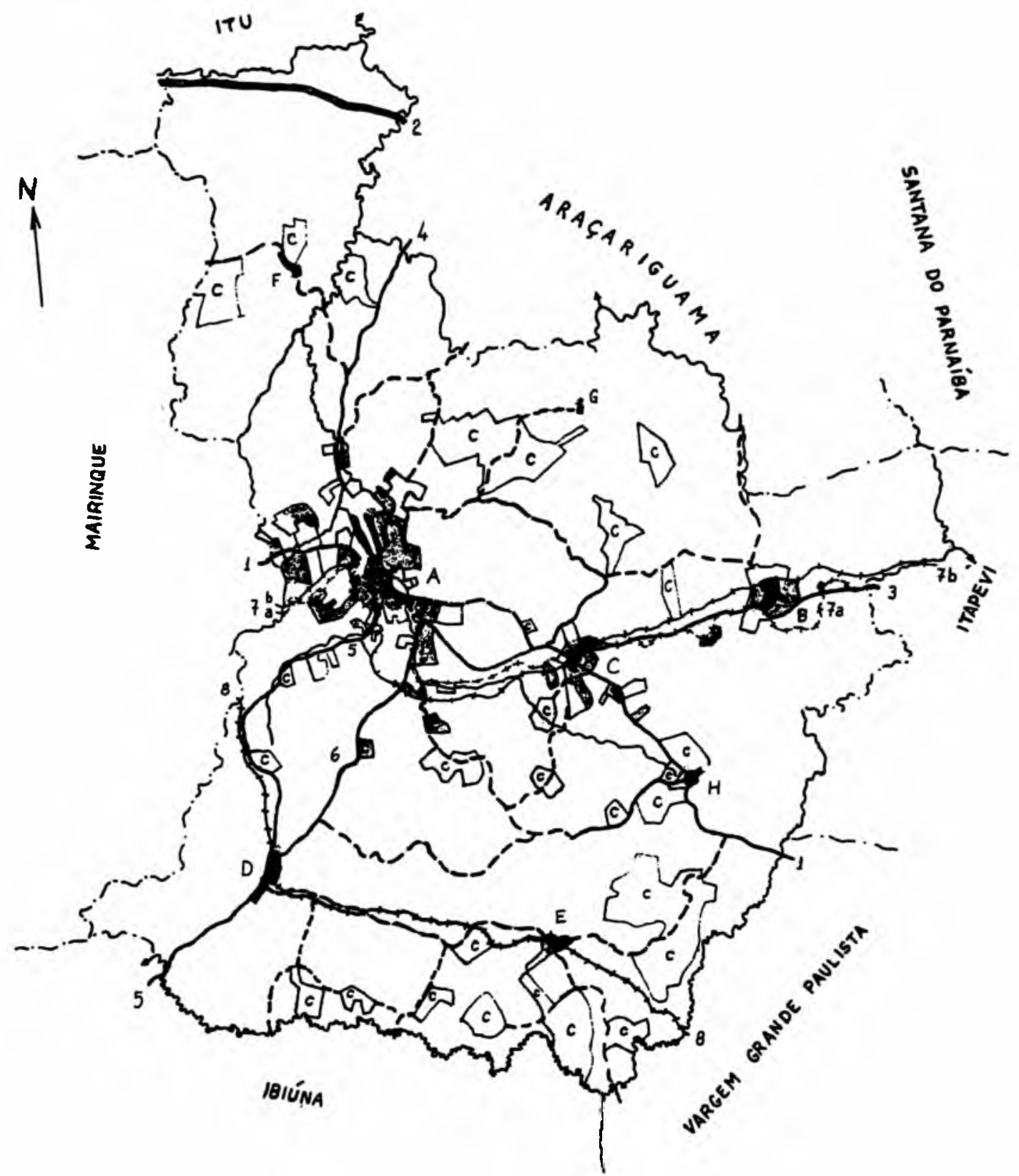

Fig. 4 Munićpio de São Roque com suas áreas urbanas/urbanizadas e sistema viário principal, a partir de fontes cadastrais da prefeitura municipal e textos de Santos (1938) e Gaspar (1930) - 1995. 


\section{RESULTADOS E DISCUSSÃO}

Analisando-se os textos legais citados verifica-se que são as seguintes as áreas cujas formações vegetais deveriam ser mantidas inalteradas e que podem ser aplicadas ao município de São Roque:

1. Pelo Código Florestal (leis n. 4.771/65, n. 7.511/86 e n. 7.803/ 89) e resolução Conama n. 4/85.

Obs.: A Lei n. 6.535/78, como citada na introdução, refere-se às áreas metropolitanas, o que não cabe no presente trabalho, uma vez que o município de São Roque não faz parte da Região Metropolitana de São Paulo.

\subsection{Art. $2^{\circ}$ Código Florestal/art. $3^{\circ}$ res. Conama.}

1.1.1. Faixa marginal de $30 \mathrm{~m}$ para rios de até $10 \mathrm{~m}$ de largura.

Obs. 1: No município, os rios não excedem esta largura em condições normais de pluviosidade, salvo em ocasiões excepcionais.

Obs. 2: Neste caso, segundo a resolução Conama n. 4/85, somente a faixa marginal de $5 \mathrm{~m}$ mais próxima do leito é considerada como reserva ou estação ecológica (art. 3o, b, 1);

1.1.2. Redor de lagoas, lagos ou reservatórios naturais ou artificiais situadas em perímetro urbano.

Obs.: Todas as áreas são incluídas no perímetro urbano definido em lei pela prefeitura local.

1.1.3. Nascentes, ainda que intermitentes, mesmo os chamados "olhos d'água", qualquer que seja a sua situação topográfica num raio mínimo de $50 \mathrm{~m}$ de largura. 
1.1.4. Topo dos morros, montes, montanhas e serras.

Obs.: A resolução Conama n. 4/85, art. $3^{\circ}$, b, IV e $V$, define essas áreas "a partir da curva de nível correspondente a $2 / 3$ da altura mínima da elevação em relação à base";

1.1.5. Linhas de cumeada, "em área delimitada a partir da curva de nível correspondente a $2 / 3$ da altura, em relação à base, do pico mais baixo da cumeada, fixando-se a linha de nível para cada segmento de cumeada equivalente a 1.000 metros"

1.1.6. Encostas ou partes destas com declividade superior a $45^{\circ}$, equivalente a $100 \%$ na linha de maior declive.

\subsection{Art. 10 Cód. florestal.}

1.2.1. Áreas com inclinação entre $25^{\circ}$ e $45^{\circ}(46,6 \%$ e $100 \%$, respectivamente), onde a derrubada de florestas não é permitida, "só sendo nelas tolerada a extração de toros quando em regime de utilização racional, que vise a rendimentos permanentes.

1.3. Art. 16 Cód. florestal.

1.3.1. $20 \%$ de cada propriedade rural deve ser mantida com vegetação primitiva.

$\S$ único - Para propriedades entre 20 e 50 ha, qualquer cobertura vegetal poderá ser utilizada para compor o limite (nativa, frutícola, ornamental, industrial).

Obs.: Este item não foi cartografado por não se ter um mapa da distribuição fundiária do município e também por não serem estas propriedades objetos do presente estudo.

2. Pela Lei 6.766/79 (Lei Lehmann).

Obs.: Neste caso, prevêem-se as áreas que não podem ser parceladas para fins urbanos. 
2.1. art. $3^{\circ}$ Terrenos alagadiços e sujeitos a inundações, antes de tomadas as providências para assegurar o escoamento das águas.

2.1.1. Terrenos que tenham sido aterrados com material nocivo à saúde pública, sem que sejam previamente saneados.

2.1.2. Terrenos com declividade superior a $30 \%$ (ou $16^{\circ} 42^{\prime}$ ), salvo se atendidas as exigências específicas das autoridades competentes.

2.1.3. Terrenos onde as condições geológicas não aconselham as edificações.

Obs.: Este item não foi cartografado porque não há dados geotécnicos para a área.

2.1.4. Em áreas de preservação ecológica ou naquelas onde a poluição impeça condições sanitárias suportáveis, até a correção.

Obs.: Por este item, a Lei 6.766/79 faz uma referência indireta à legislação específica de preservação ambiental. Dessa forma, as áreas previstas no código florestal e resolução Conama n. 4/85 não são passíveis de parcelamento urbano, como será discutido mais adiante.

2.2. art. 4 - Ao longo das águas correntes e dormentes e das faixas de domínio público das rodovias, ferrovias e dutos, será obrigatória a reserva de uma faixa "non aedificandi" de 15 metros de cada lado, salvo maiores exigências da legislação específica.

Obs.: Neste caso, o código florestal é mais restritivo para os corpos d'água, exigindo no mínimo $30 \mathrm{~m}$ marginais.

A Tabela 1 mostra a relação entre a declividade, em graus e em porcentagem, e as restrições previstas em lei. A Figura 5 mostra essa mesma relação esquematicamente. Como se utilizou uma 
equidistância vertical de 25 m para uma escala de 1:10.000, não foi possível avaliar com maior precisão as áreas equivalentes a cada intervalo de declividade. Os resultados, portanto, estão submensurados, ou seja, áreas de preservação permanente definidas pela declividade são maiores que o especificado no exercício. Mesmo assim, o erro não é muito grande, podendo os dados serem utilizados como referência. De qualquer forma, mesmo nesse nível de resolução cartográfica, já se verificam infrações, com parcelamento e uso urbano nessas áreas.

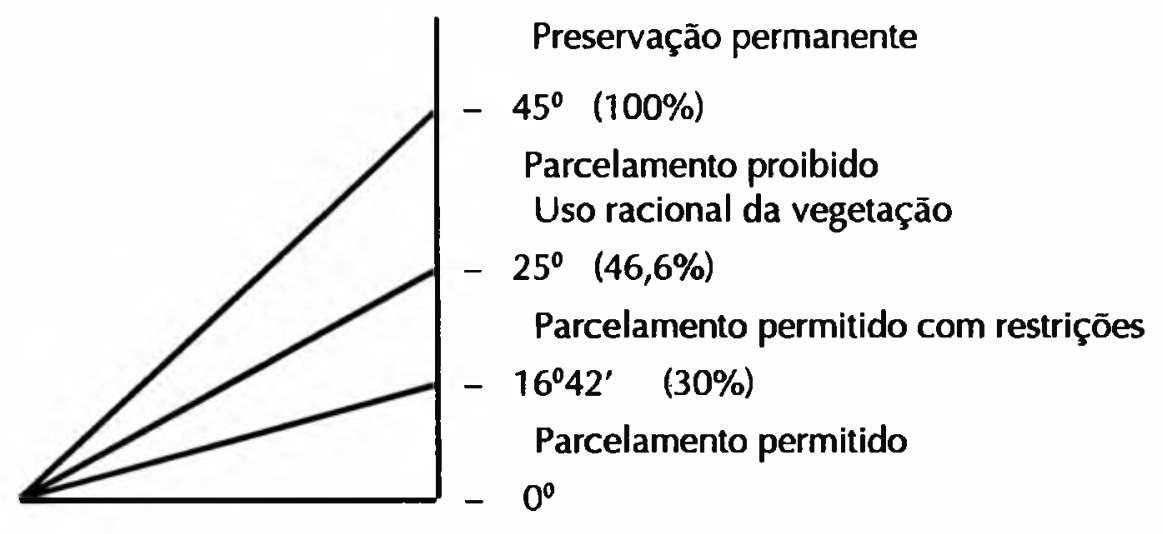

Figura 5 - Esquema gráfico das restriçỏes legais em função da declividade dada em ângulo e em porcentagem.

O código florestal e a resolução Conama n. 4/85 apresentam as restrições de modo que seus limites podem ser bem definidos cartograficamente. No entanto, encontrou-se uma grande dificuldade para espacializar-se o previsto na alínea " $d$ " do art. $2^{\circ}$ do código, correspondente ao art. $3^{\circ}, b, \vee$ da resolução, que se refere à cobertura vegetal no topo de morros, montes, montanhas e serras, bem como nas linhas de cumeada (art. $3^{\circ}$, b, VI, da resolução). Seguindo o texto legal, a delimitação dos $2 / 3$ referidos, ao menos na área de estudo, é muito difícil, parecendo-nos impraticável em áreas com as características fundiárias e ambientais (tipo de relevo) que o município apresenta. Englobaria extensas áreas, tomando propriedades inteiras, já que as áreas das propriedades são relativamente pequenas. $\mathrm{E}$ em termos geomorfológicos, a linha de nível definida pelos $2 / 3$ acabaria por envolver inclusive áreas de fundo de vale, demons- 
trando que o texto, neste aspecto é extremamente genérico e não condiz com a realidade. A Figura 6 apresenta um esquema demonstrando a dificuldade encontrada na espacialização dessas restrições de caráter geomorfológico. Sendo assim, no presente trabalho levou-se em consideração apenas os topos de elevações geomorfologicamente definidos. De qualquer forma, pelo que se observa nos mapas anexos (Figuras 7 a 10), onde foram marcados os topos e as principais linhas de cumeada, tais áreas de preservação permanente já se encontram bastante ocupadas. O sistema viário principal ocupa em muitos trechos as linhas de cumeada, condicionando, assim, uma tendência a ocupar-se essa área com usos antrópicos mais transformadores da paisagem.

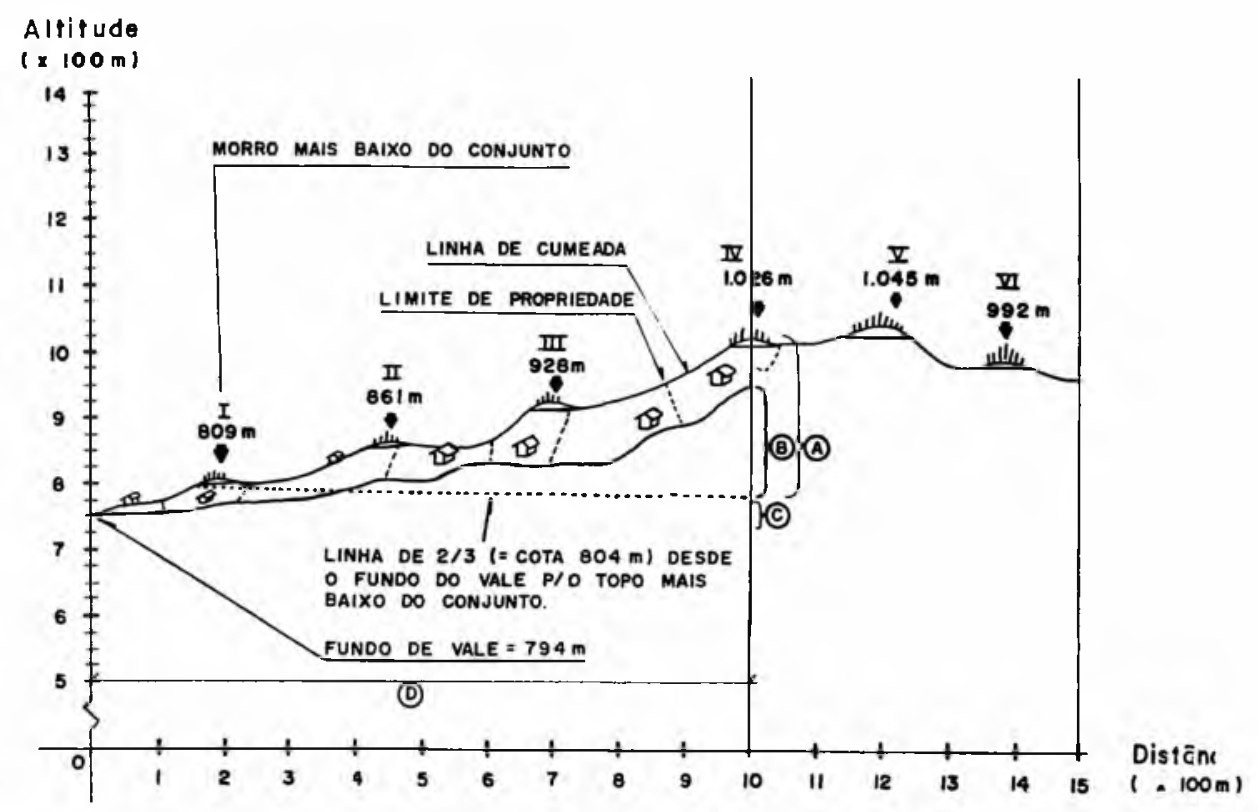

Fig. 6 - Esquema de aplicação do codigo florestal (art. 2, d)/ resolução Conama n. 4/85 (art. $3^{\circ}, 6, V$ e VI), mostrando que a linha dos $2 / 3$ chega ao fundo do vale e abrange propriedades inteiras na área de preservação permanente. (explicação no texto). 

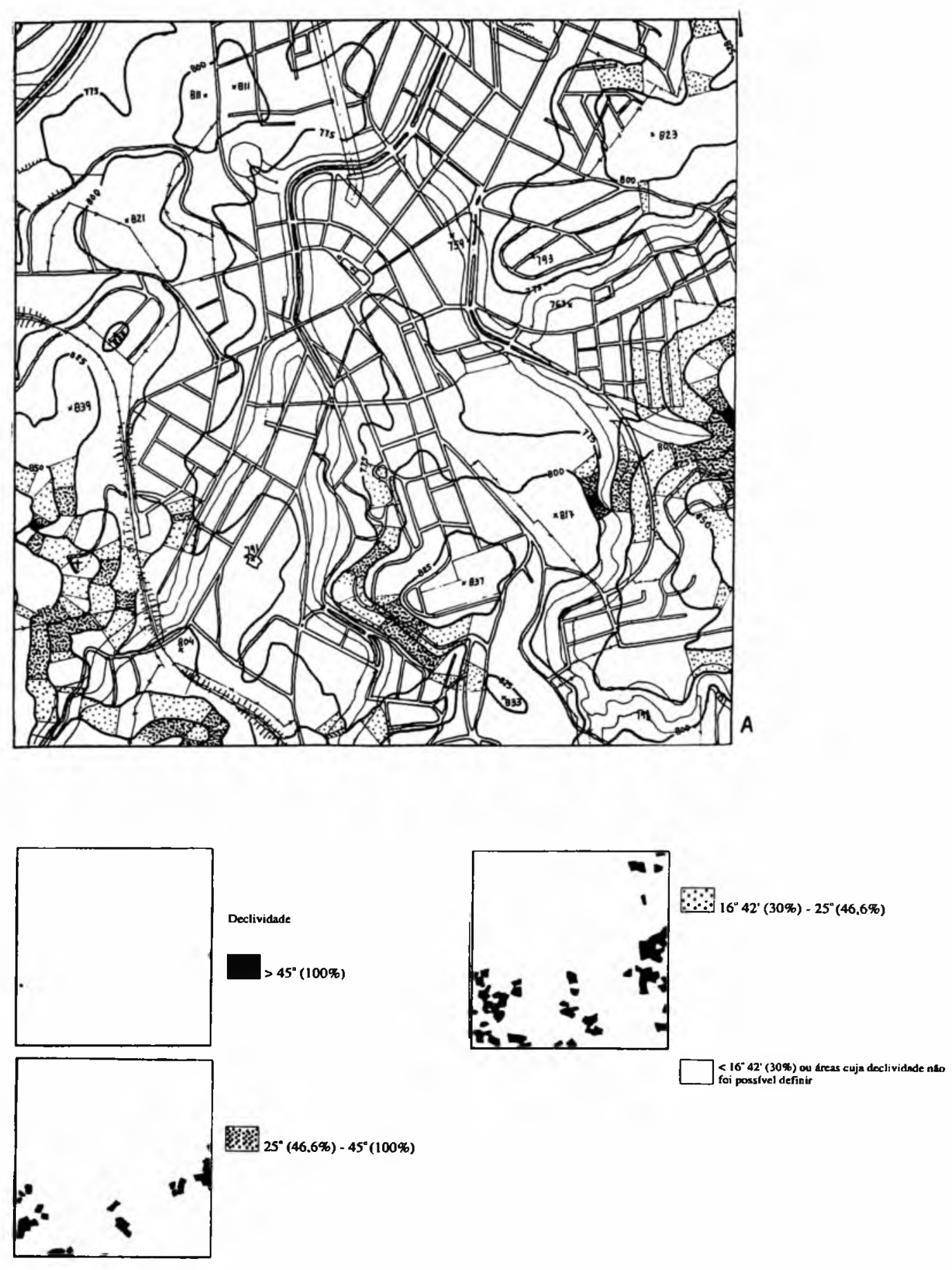

Fig. 7 - Mapa de áreas urbanizadas e restriçōes legais. Area amostral 1: Centro - São Roque (SP). 1994. A - Carta de declividade B - Areas urbanizadas com sistema de recreio e restrições de caráter hidrográfico (margens e nascentes) e de relevo (topos de elevações e linhas de cumeada) 

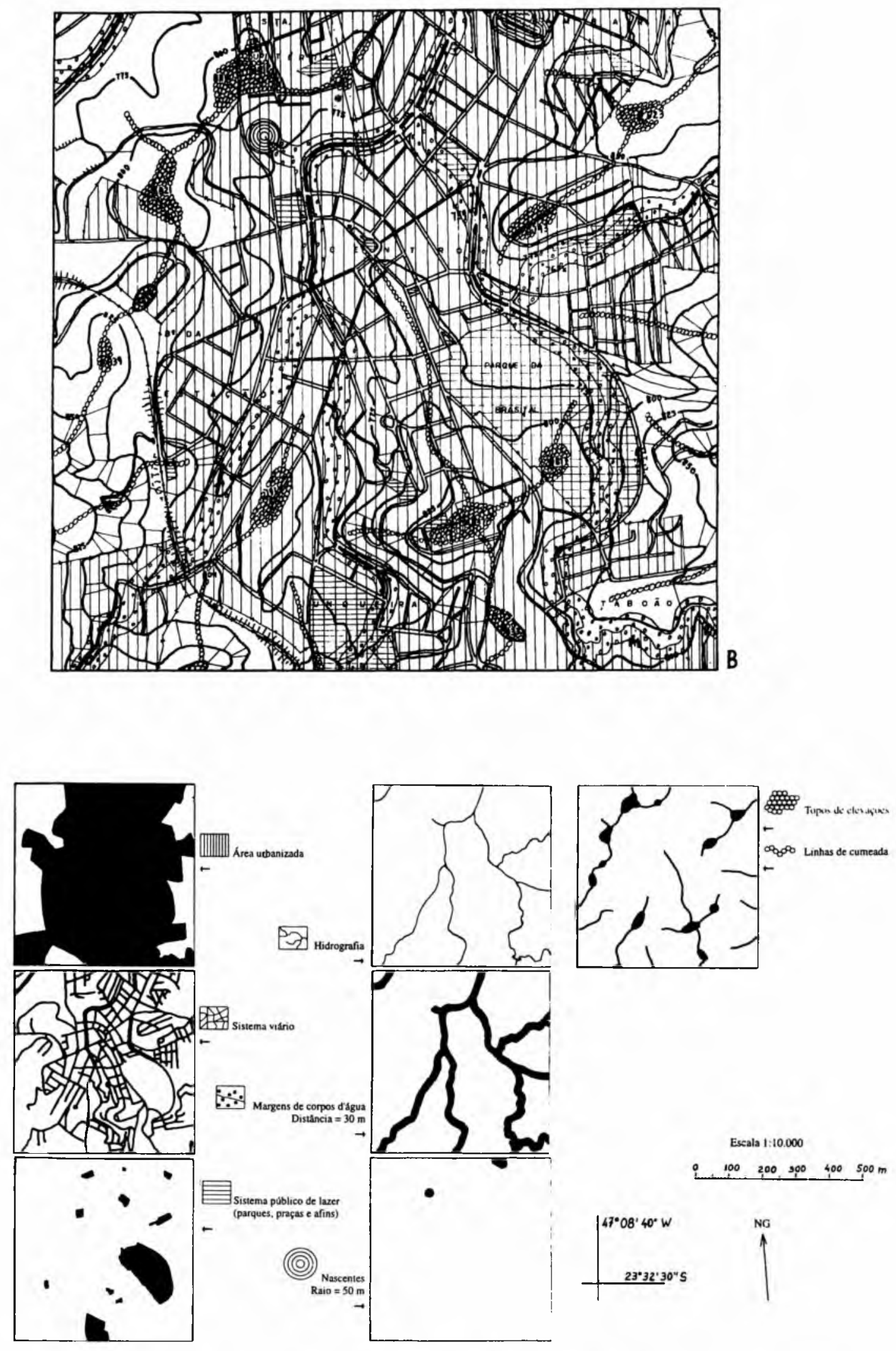

Paisagem Ambiente Ensaios São Paulo n. 8 p. 105 - 144 dez. 1995 

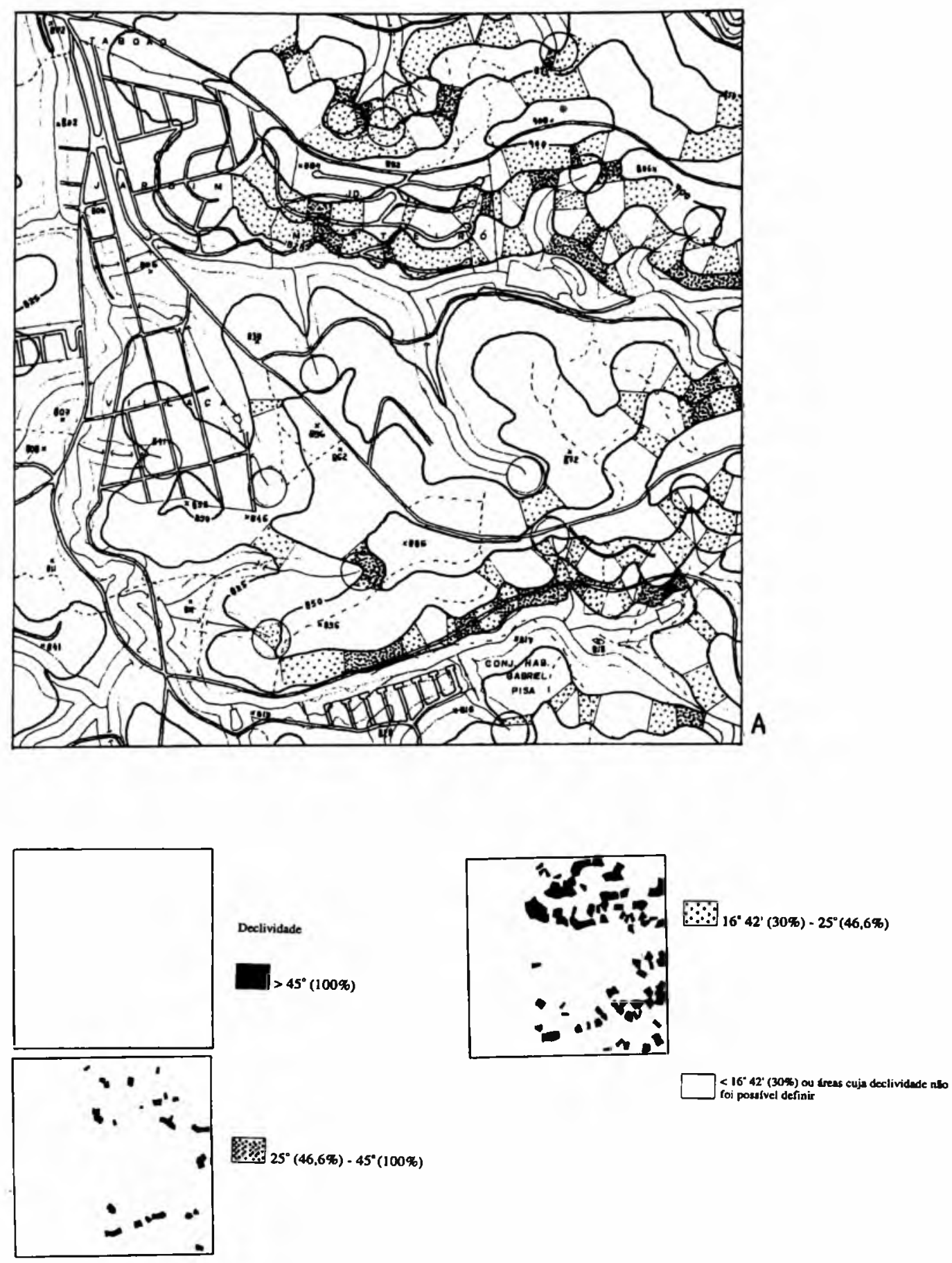

Fig. 8 - Mapa de áreas urbanizadas e restriçōes legais. Area amostral: Taboão - São Roque (SP). 1994. A - Carta de declividade

B - Areas urbanizadas com sistema de recreio e restrições de caráter hidrográfico (margens e nascentes rios) $e$ de relevo (topos de elevações e linhas de cumeada) 

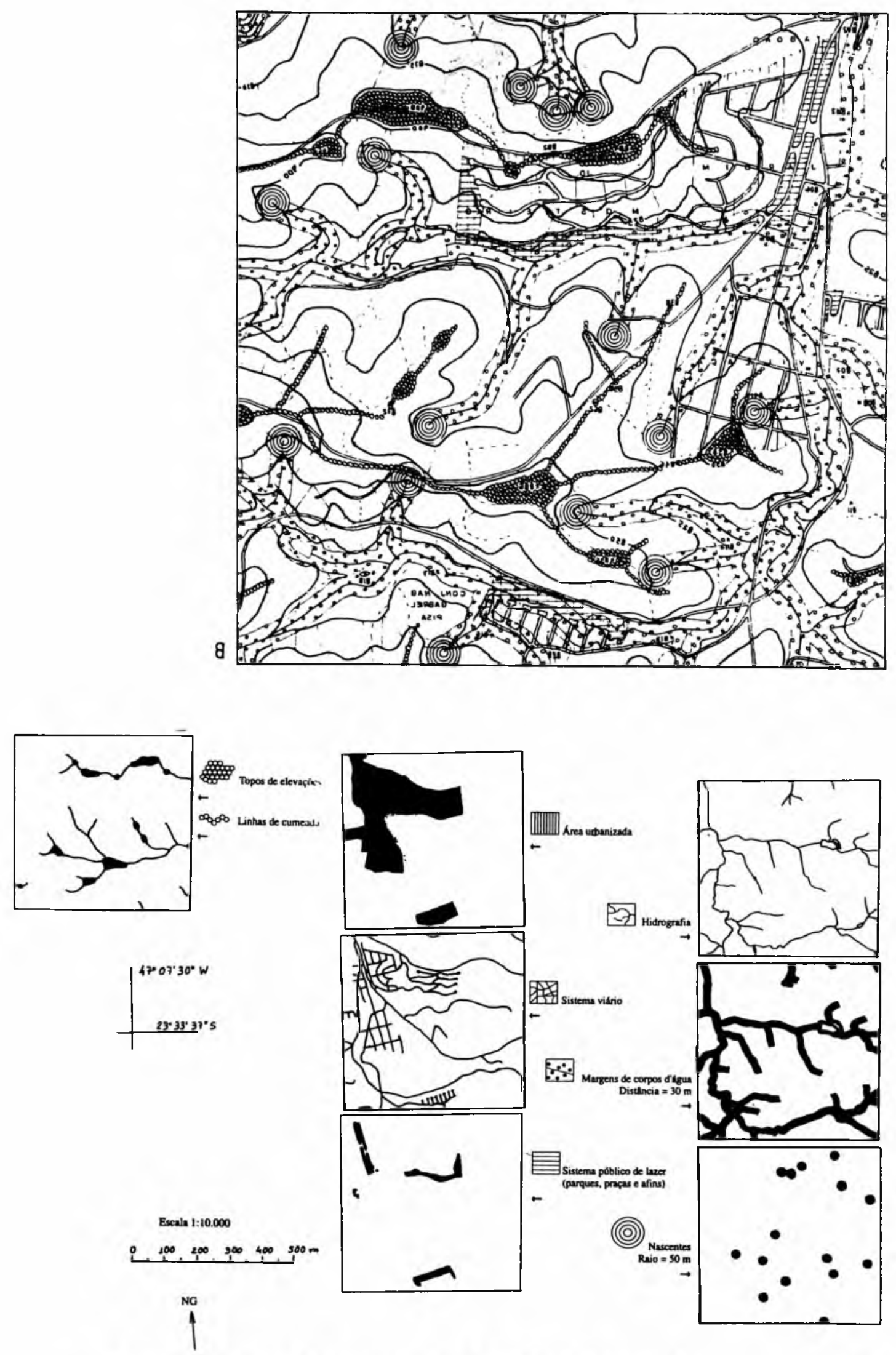

Paisagem Ambiente Ensaios São Paulo n. 8 p. 105 - 144 dez. 1995 

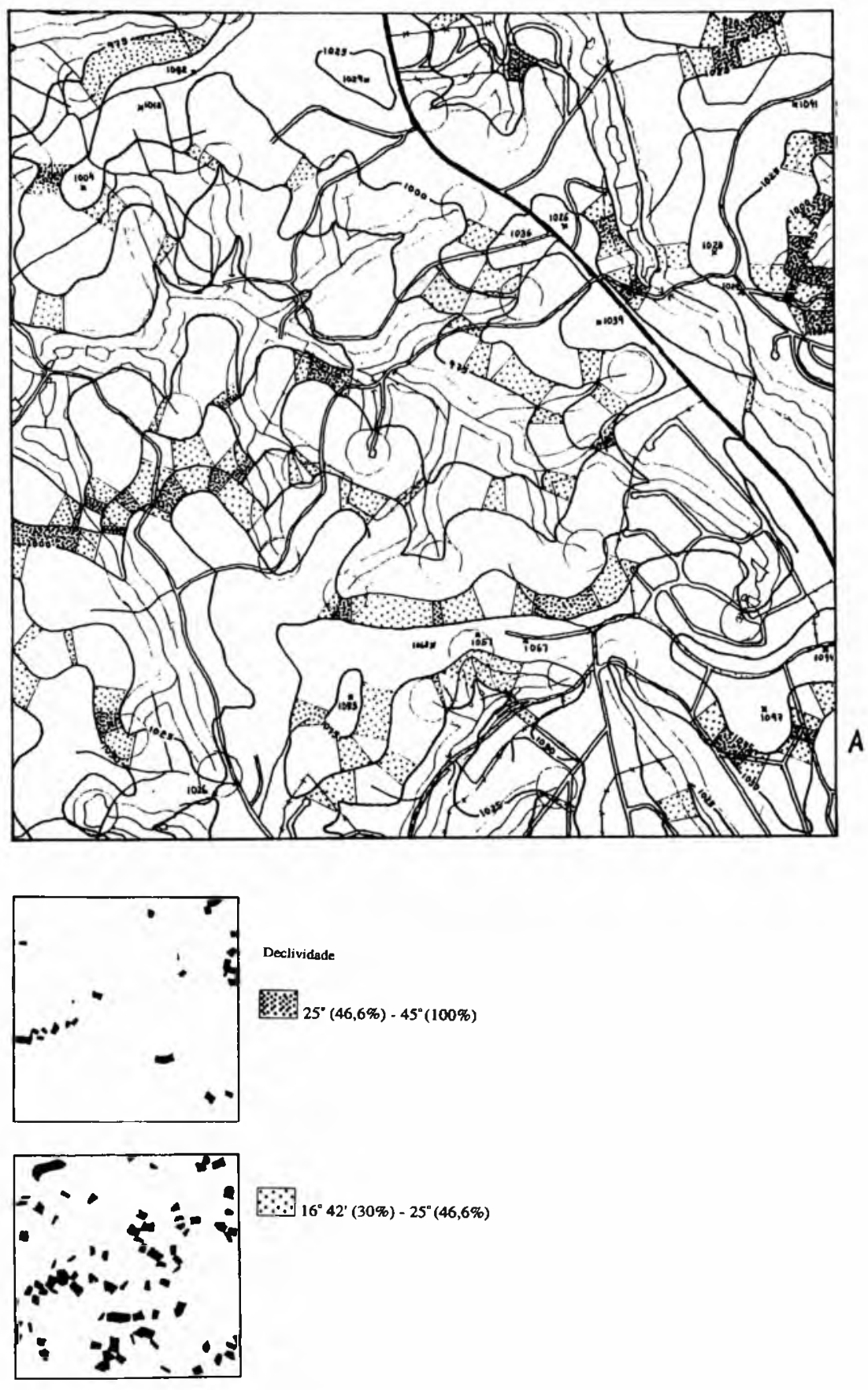

Fig. 9 - Mapa de áreas urbanizadas e restrições legais. Area amostral 3: Alto da Serra - São Roque (SP). 1994. A - Carta de declividade

$B$ - Areas urbanizadas com sistema de recreio e restriçôes de caráter hidrográfico (margens e nascentes rios) e de relevo (topos de elevações e linhas de cumeada) 

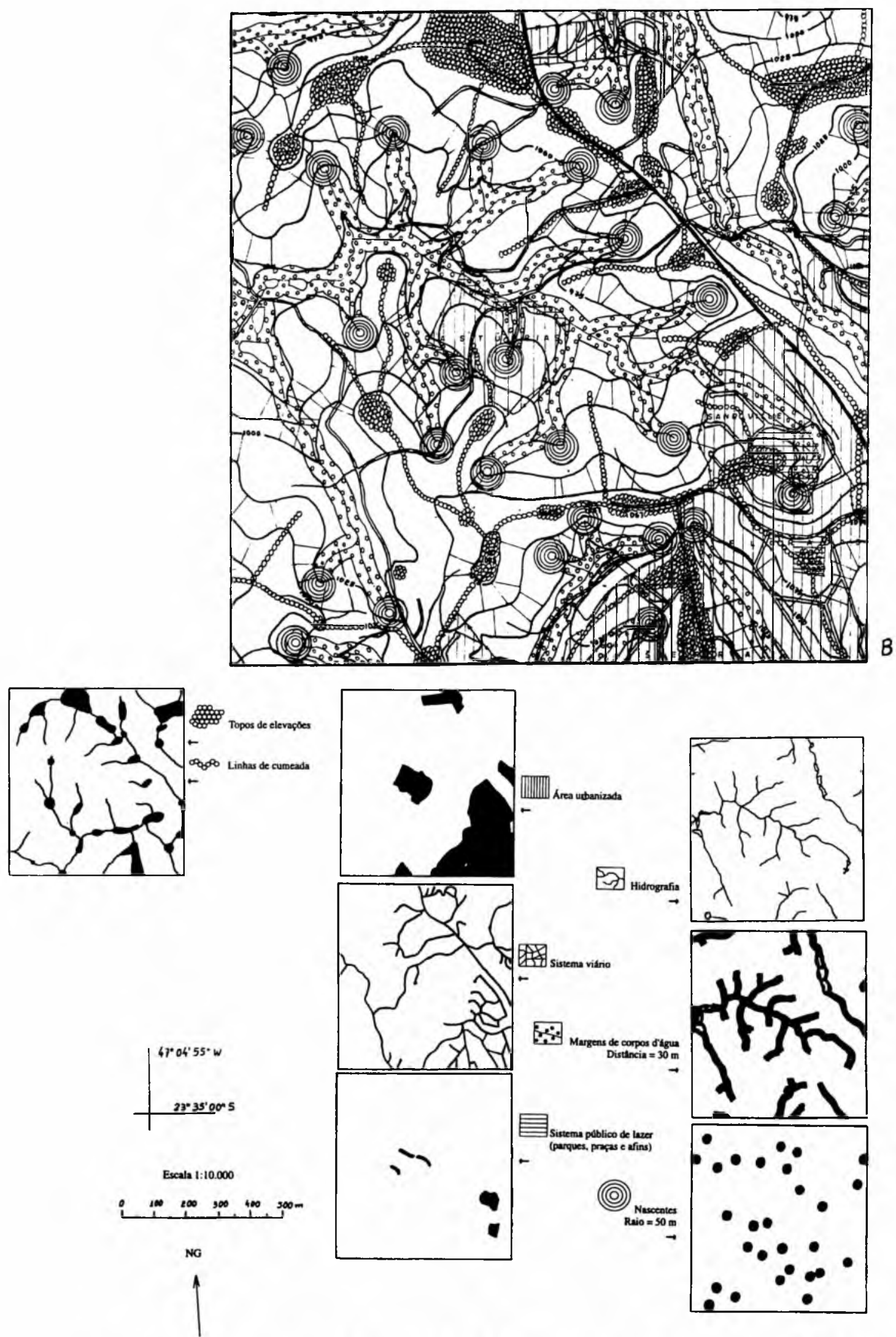

Paisagem Ambiente Ensaios São Paulo n. 8 p. 105 - 144 dez. 1995 

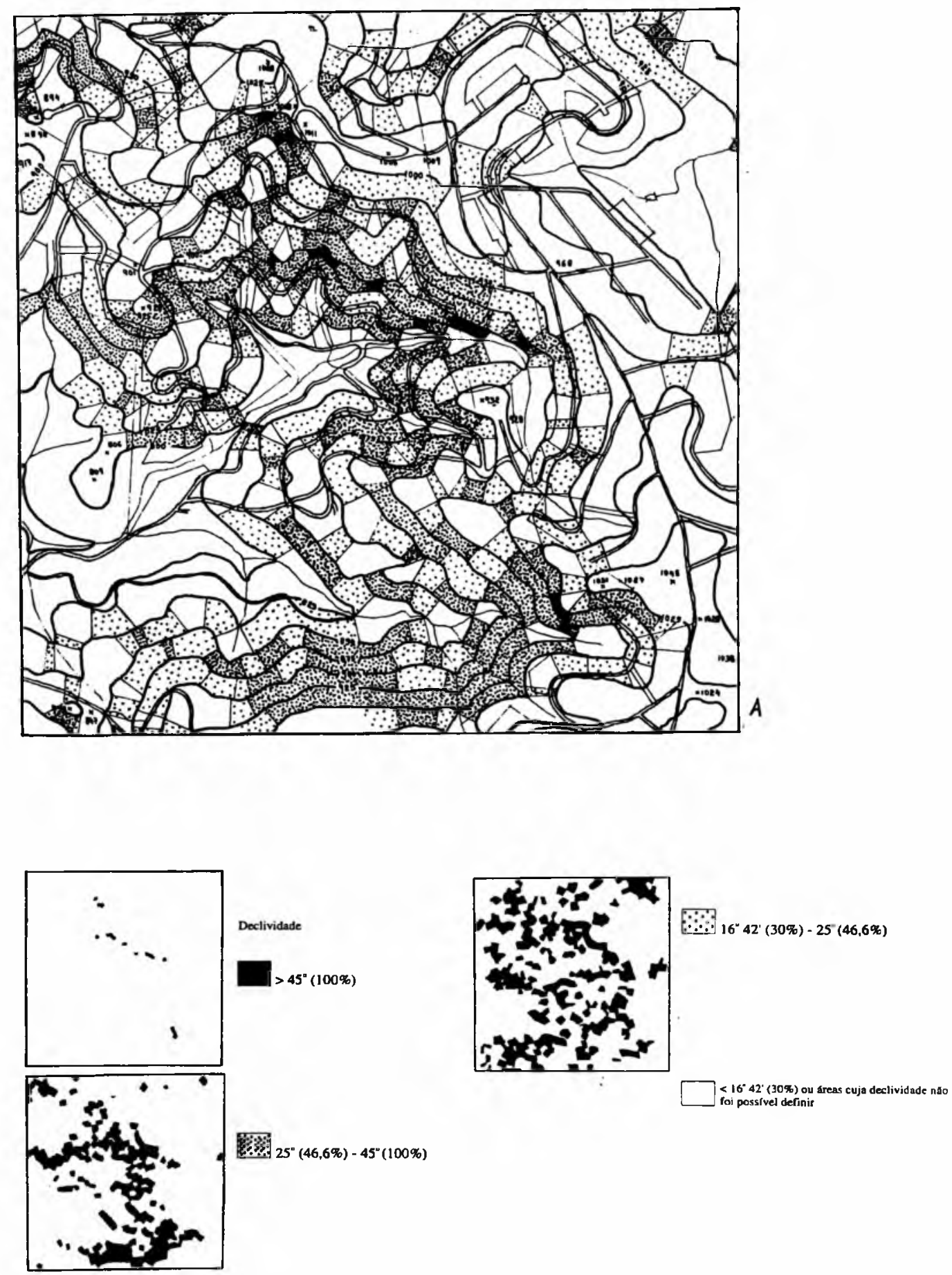

Fig. 10 - Mapa de áreas urbanizadas e restrições legais. Area amostral 4: Cambará - São Roque (SP). 1994. A - Carta de declividade

$B$ - Areas urbanizadas com sistema de recreio e restrições de caráter hidrográfico (margens e nascentes rios) e de relevo (topos de elevações e linhas de cumeada) 

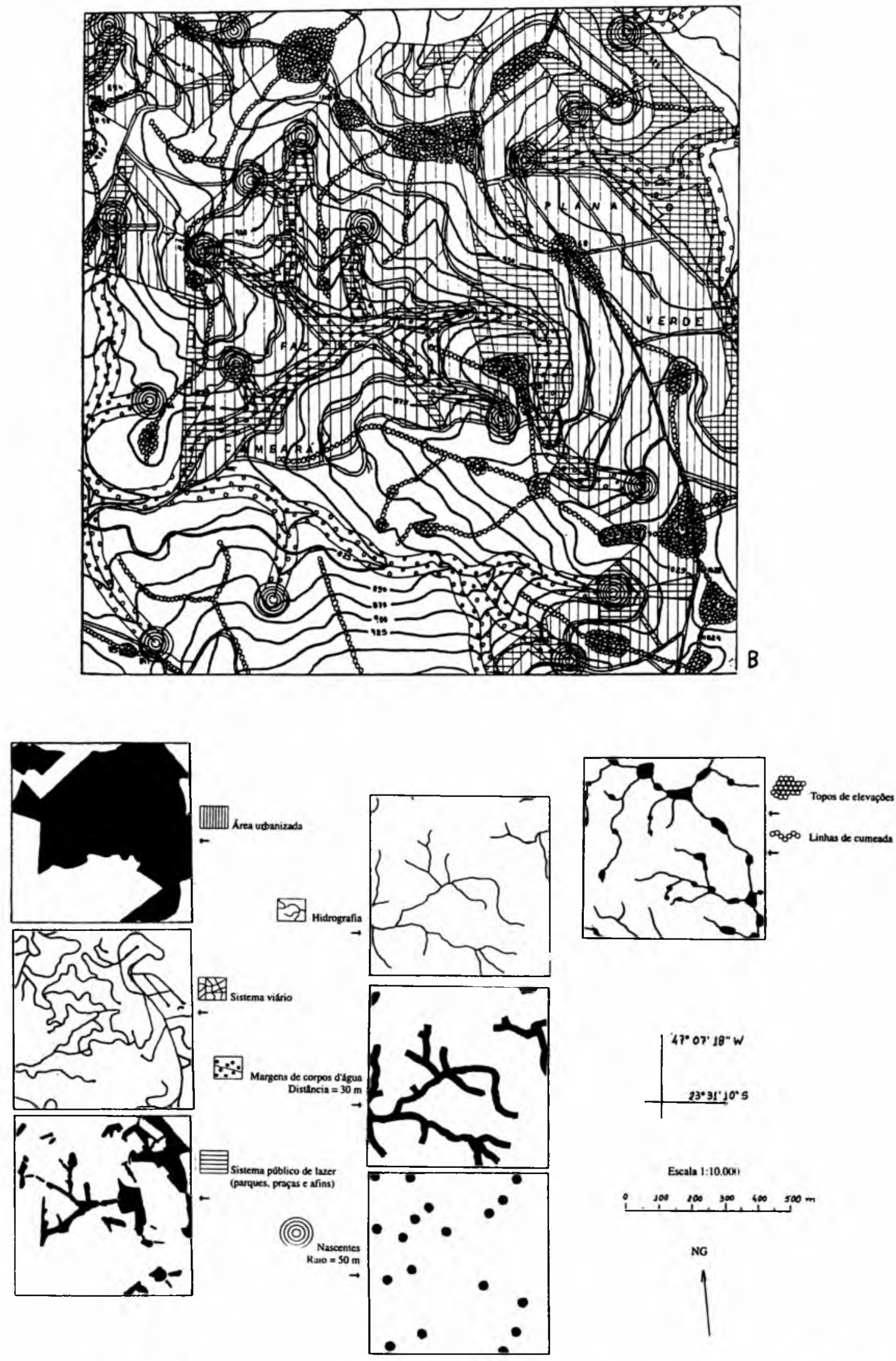

Paisagem Ambiente Ensaios São Paulo n. 8 p. 105 - 144 dez. 1995 
Com relação à Lei 6.766/79, observa-se que seu texto aponta as restrições e em seguida já apresenta condições em que o parcelamento pode ser realizado nessas mesmas áreas restringidas. Os termos "antes de", "sem que" e "salvo se" indicam o caráter condicional da lei. Eles implicam na exclusão do uso urbano e na prévia correção do possível problema para que este uso possa ser implementado. Coloca-se como um texto tecnicista, onde a tecnologia vem possibilitar o uso e a ocupação, escoando-se as águas, saneando-se aterros, fazendo-se obras de engenharia em encostas, despoluindo-se, etc. Atendidas as exigências, praticamente todo e qualquer lugar pode ser objeto de parcelamento e ocupação. A única exceção é o item que se refere às áreas de preservação ecológica, o que acaba remetendo à legislação específica. O grande avanço desta lei, como observa Machado (op. cit.), é a obrigatoriedade de se evitar ou corrigir previamente todas as condições negativas de sanidade pública, antes que se venha a consumar o parcelamento e a sua ocupação. Este autor ressalta ainda, que a referida lei evita ou deve ser usada para evitar - abusos por parte dos loteadores, exigindo aquelas "condições mínimas de sanidade para todas as comunidades da Nação"

Dessa forma, verifica-seque a Lei 6.766/79 em geral só condiciona genericamente as formas de uso e ocupação, visando basicamente a sanidade pública dos parcelamentos, enquanto que o código florestal e a resolução Conama n. 4/85 definem exatamente quais áreas não podem ser objeto de uso que não seja o de conservação e preservação permanente dos ecossistemas naturais.

Apesar de a Lei 6.766/79 referir-se às áreas de preservação ambiental em seu texto e, dessa forma, remeter-se à legislação específica, esta não é seguida pelos agentes do parcelamento do solo, incluindo o poder público.

Observando-se as Figuras 7 a 10, nota-se que a legislação tem sido amplamente infringida. Em alguns casos, o parcelamento do solo precede a legislação, ou foi realizado quando as 
exigências legais eram menos restritivas. Por exemplo, a largura marginal dos rios que devem ser mantidas florestadas; foi de 10 m de largura a partir de 1965, ano de promulgação do novo código florestal, até 1986, quando passou para $30 \mathrm{~m}$ de acordo com o novo texto dado pela Lei 7.511/86. Como a lei não é retroativa, essas áreas como as demais previstas deixam de ser objeto de aplicação da lei. Por outro lado, Machado (op. cit.), citando o prof. Hely Lopes Meirelles, afirma que, embora o parcelamento seja anterior à lei, os usos que venham a ser feitos nos terrenos vagos regem-se pelos dispositivos da lei em vigência. No entanto, mesmo os loteamentos mais recentes não seguem o que preconiza a lei.

Gonçalves (1991) sustenta que a lei protege apenas as formações vegetais e não o sítio onde essas formações porventura estejam ambientadas e que a lei não prevê a recuperação dessas formações nos espaços em que elas deveriam estar protegidas. Machado (op. cit.), no entanto, conjecturando sobre essa questão, entende, com base no que diz o art. 18 do código florestal, que em não havendo, por qualquer que seja o motivo, formação vegetal nativa nos espaços destinados à preservação permanente, nenhum outro uso poderá neles ser efetuado, já que a lei prevê o florestamento ou reflorestamento das áreas. Corroborando essa interpretação, o art. 225, § 1ํ, VII, da Constituição Federal, diz que a alteração e a supressão dos espaços territoriais e seus componentes especialmente protegidos só podem ser permitidas através de lei, "vedada qualquer utilização que comprometa a integridade dos atributos que justifiquem sua proteção". Sendo tais áreas já definidas em lei como estações ecológicas, e antes como de preservação permanente, sua utilização não pode ser outra que não seja a de proteção ambiental.

Interessante notar que o próprio poder público, que deveria fiscalizar e fazer cumprir a lei, tem sido não apenas conivente com a prática como ele próprio tem sido agente infrator. É o caso como pode ser visualizado na Figura 8 , junto ao lado inferior, da ocupação indevida das margens do córrego Aracaí e de um afluente seu e vertentes próximas por um conjunto habitacional. 
O leito do córrego foi retificado através de cortes e aterros no terreno para dar lugar à terraplenagem onde foram traçadas as ruas e erguidas as casas. A partir desse ponto o rio torna-se meandrante até o desnível abrupto - cerca de $25 \mathrm{~m}$ localizado junto ao Parque da Brasital próximo ao centro da cidade (Figura 7), aproximadamente $3,5 \mathrm{~km}$ à jusante. Uma vez retificando-se e canalizando-se o curso d'água, como tem sido prática comum nas áreas urbanas, diminui-se o percurso das águas e conseqüentemente aumenta-se sua velocidade, com menor tempo de deslocamento, ou seja, o tempo de concentração diminui. $O$ resultado desse processo são as enchentes e, a longo prazo, problemas quanto à recarga e manutenção dos níveis hídricos dos aqüíferos. Naturalmente que diversos são os fatores intervenientes no processo, contudo, mantidas as tendências de urbanização da bacia, especialmente nos moldes que vem sendo feita, a probabilidade de ocorrência de enchentes aumenta.

Analisando-se a Tabela 2, verifica-se que as áreas de preservação permanente ocupam em média $30 \%$ das áreas amostradas, variando de $17,50 \%$ no Centro (Figura 7), espaço mais antigo e mais densamente ocupado, até 41,25\% no Cambará (Figura 10), onde predominam loteamentos de chácaras com baixa densidade populacional, apesar da proximidade com o centro da cidade. Isso resulta numa média de $70 \%$ ou $2.800 .000 \mathrm{~m}^{2}$ $\left(2,8 \mathrm{~km}^{2}\right)$ de áreas parceláveis. Considerando que somente $65 \%$ desse valor pode ser de uso privado - os lotes propriamente ditos - ter-se-ia em média $1.820 .000 \mathrm{~m}^{2}$, ou $45,50 \%$, das áreas amostrais passíveis de uso como lote urbano. Mesmo na área de maior ocupação com espaços de preservação ambiental (Cambará), esse índice seria de $38,18 \%$, exclusivamente destinados a lotes urbanos, já descontados os espaços ocupados com sistema viário, usos institucionais (escolas, posto de saúde, posto policial, etc.), sistema de recreio ( $10 \%$ da área parcelável) e o próprio sistema de preservação ambiental. O centro, com $82,50 \%$, seria aárea com mais espaços passíveis de parcelamento, seguido do bairro vizinho, o Taboão (Figura 8), com 71,50\%. Essas duas áreas estão posicionadas mais no centro da bacia hidrográfica, onde o relevo já é mais suavizado, com declividades 
menos acentuadas e menos pontos de nascentes. As duas outras áreas situam-se exatamente nos limites da bacia, onde o relevo é mais movimentado, com desníveis e declividades mais acentuados, e maior incidência de nascentes. Igualmente, as linhas de cumeadas e os topos têm maior representatividade junto aos limites da bacia (Cambará e Alto da Serra, Figura 9). Assim sendo, as próprias características ambientais já condicionariam regiões mais e menos urbanizadas e, contrariamente, menos e mais naturais, sem haver, entretanto, situações extremas.

Em termos de densidade populacional, verifica-se que com os três tamanhos hipotéticos de lote $\left(250,500\right.$ e $\left.1.000 \mathrm{~m}^{2}\right)$ e uma densidade média hipotética de 5 habitantes por lote (domicílio) poder-se-ia ter uma população absoluta de 30.540, $15.270 \mathrm{ou}$ 7.635 habitantes, respectivamente, para a área mais restrita (Cambará) e de 42.900, 21.450 ou 10.725 habitantes, respectivamente, para a menos restrita (Centro). Considerando que o município como um todo tem hoje uma população estimada de 59.833 habitantes (Seade, 1.994), espalhados por $313 \mathrm{~km}^{2}$ (Seade, 1993), somente essas duas áreas, num total de $8 \mathrm{~km}^{2}$, seriam suficientes para abrigar sua população atual, em lotes de $250 \mathrm{~m}^{2}$, mantendo toda a infra-estrutura urbana e os espaços de preservação ambiental implantados. Considere-se, ainda, que a densidade média por lote usada é alta, se comparada com a divulgada pelo IBGE (1991) que para esta data foi de 3,88 hab./ domicílio. Neste trabalho, considerou-se também apenas a urbanização horizontal, ou seja, construções unifamiliares em cada lote.

É evidente que existe todo um complexo fundiário, e daí sócioeconômico, que deve ser levado em consideração. No entanto, esse simples exercício demonstra que, quando do parcelamento de uma propriedade maior, a observação da legislação não impede que se possa conciliar todos os usos que determinada área possa abrigar. 
Tabela 2 - Comparaçôes entre as áreas amostrais quanto a áreas de preservação permanente, áreas parceláveis, usos institucionais, sistemas de recreio, números hipotéticos de lotes, densidades populacionais absolutas e relativas e indices de sistema de recreio e de preservação permanente em função da espacialização da legislação ambiental aplicada ao municlpio de São Roque (SP) (1994).

\begin{tabular}{|c|c|c|c|c|c|c|}
\hline$n^{2}$ & Descrição & Centro & Taboāo & $\begin{array}{l}\text { Alto da } \\
\text { Serra }\end{array}$ & Cambará & $\begin{array}{l}\text { Valores } \\
\text { médios }\end{array}$ \\
\hline 1 & Área total $\left(\mathrm{m}^{2}\right)$ & 4.000 .000 & 4.000 .000 & 4.000 .000 & 4.000 .000 & 4.000 .000 \\
\hline 2 & $\begin{array}{l}\text { Área total não parcelável; pres. perm. } \\
\text { (valores aprox. em m²) }\end{array}$ & 700.000 & 1.100 .000 & 1.350 .00 & 1.650 .000 & 1.200 .000 \\
\hline $2 a$ & Margens $(30 \mathrm{~m})$ & 460.000 & 775.000 & 665.000 & 560.000 & 615.000 \\
\hline $2 b$ & Nascentes (raio $=50 \mathrm{~m}$ ) & 20.000 & 105.000 & 240.000 & 160.000 & 131.250 \\
\hline $2 c$ & Topos de morros & 122.000 & 119.000 & 360.000 & 220.000 & 205.250 \\
\hline $2 d$ & Declividade acima de $45^{\circ} / 100 \%$ & 3.000 & 1.000 & - & 15.000 & 4.750 \\
\hline $2 \mathrm{e}$ & Declividade entre $25^{\circ}(46,6 \%)$ e $45^{\circ}(100 \%)$ & 95.000 & 100.000 & 85.000 & 695.000 & 243.750 \\
\hline 3 & Índice de área não parcelável $(2 \times 1)(\%)$ & 17,50 & 27,50 & 33,75 & 41,25 & 30,00 \\
\hline 4 & Área parcelável $\left(\mathrm{m}^{2}\right)$ & 3.300 .000 & 2.900 .000 & 2.650 .000 & 2.350 .000 & 2.800 .000 \\
\hline 5 & Indice de área parcelável $(4 \times 1)(\%)$ & 82,50 & 72,50 & 66,25 & 58,75 & 70,00 \\
\hline 6 & $\begin{array}{l}\text { Área institucional }=35 \%\left({ }^{*}\right) \\
\text { sobre área parcelável }(4)\left(\mathrm{m}^{2}\right)\end{array}$ & 1.155 .000 & 1.015 .000 & 927.500 & 822.500 & 980.000 \\
\hline 7 & $\begin{array}{l}\text { Área privada }=65 \%\left({ }^{* *}\right) \\
\text { sobre área parcelável }(4)\left(m^{2}\right)\end{array}$ & 2.145 .000 & 1.885 .000 & 1.722 .500 & 1.527 .500 & 1.820 .000 \\
\hline 8 & Índice de área privada $(7 \times 1)(\%)$ & 53,62 & 47,12 & 43,06 & 38,18 & 45,50 \\
\hline 9 & $\begin{array}{l}\text { Área de sistema de recreio }=10 \%\left({ }^{* * *}\right) \\
\text { sobre área parcelável }\left(\mathrm{m}^{2}\right)\end{array}$ & 330.000 & 290.000 & 265.000 & 235.000 & 280.000 \\
\hline 10 & $\begin{array}{l}\text { Número de lotes possivel com áreas } \\
\text { de } 1.000 / 500 / 250 \mathrm{~m}^{2} \text { por lote }(7 \times 10)\end{array}$ & $\begin{array}{l}2.145 \\
4.290 \\
8.580 \\
\end{array}$ & \begin{tabular}{l|}
1.885 \\
3.770 \\
7.540 \\
\end{tabular} & $\begin{array}{l}1.722 \\
3.444 \\
6.888 \\
\end{array}$ & $\begin{array}{l}1.527 \\
3.054 \\
6.108 \\
\end{array}$ & $\begin{array}{l}1.820 \\
3.640 \\
7.280 \\
\end{array}$ \\
\hline 11 & $\begin{array}{l}\text { Dens. pop. absoluta por área } \\
\text { com } 5 \text { hab./lote }(10 \times 11)\end{array}$ & $\begin{array}{l}10.725 \\
21.450 \\
42.900 \\
\end{array}$ & $\begin{array}{r}9.425 \\
18.850 \\
37.700 \\
\end{array}$ & $\begin{array}{r}8.610 \\
17.220 \\
34.440 \\
\end{array}$ & $\begin{array}{r}7.635 \\
15.270 \\
30.540 \\
\end{array}$ & \begin{tabular}{r|}
9.100 \\
18.200 \\
34.400 \\
\end{tabular} \\
\hline 12 & $\begin{array}{l}\text { Dens. pop. relativa por área } \\
(11 \times 1)\left(\mathrm{hab} . / \mathrm{km}^{2}\right)\end{array}$ & $\begin{array}{r}2.681 \\
5.362 \\
10.724 \\
\end{array}$ & \begin{tabular}{l|}
2.316 \\
4.712 \\
9.425 \\
\end{tabular} & $\begin{array}{l}2.152 \\
4.305 \\
8.610 \\
\end{array}$ & $\begin{array}{l}1.908 \\
3.817 \\
7.635 \\
\end{array}$ & $\begin{array}{l}2.275 \\
4.550 \\
9.100 \\
\end{array}$ \\
\hline 13 & $\begin{array}{l}\text { Indice de sistema de recreio } \\
(9 \times 11)\left(\mathrm{m}^{2} / \mathrm{hab} .\right)\end{array}$ & $\begin{array}{r}30,77 \\
15,38 \\
7,79 \\
\end{array}$ & $\begin{array}{r}30,77 \\
15,38 \\
7,69 \\
\end{array}$ & \begin{tabular}{r|}
30,77 \\
15,38 \\
7,69 \\
\end{tabular} & $\begin{array}{r}30,77 \\
15,38 \\
7,69 \\
\end{array}$ & $\begin{array}{r}30,77 \\
15,38 \\
7,69 \\
\end{array}$ \\
\hline 14 & $\begin{array}{l}\text { Indice de área de pres. perm. } \\
(2 \times 11)\left(\mathrm{m}^{2} / \mathrm{hab} .\right)\end{array}$ & $\begin{array}{l}65,27 \\
32,63 \\
16,31 \\
\end{array}$ & $\begin{array}{r}116,71 \\
58,35 \\
29,17 \\
\end{array}$ & $\begin{array}{r}156,79 \\
78,39 \\
39,19 \\
\end{array}$ & $\begin{array}{r}216,11 \\
108,05 \\
54,02 \\
\end{array}$ & \begin{tabular}{r|}
132,97 \\
66,48 \\
33,24 \\
\end{tabular} \\
\hline 15 & Pop. abs. e rel. média ("***) (hab. e hab./km²) & $\begin{array}{r}25.025 \\
6.256 \\
\end{array}$ & $\begin{array}{r}21.980 \\
5.495 \\
\end{array}$ & $\begin{array}{r}20.090 \\
5.022 \\
\end{array}$ & $\begin{array}{r}17.815 \\
4.453 \\
\end{array}$ & $\begin{aligned} 21.210 \\
5.302\end{aligned}$ \\
\hline 16 & $\begin{array}{l}\text { Índice de sist. de recreio para } \\
\text { pop. absoluta média }(9 \times 16)\left(\mathrm{m}^{2} / \mathrm{hab} \text {. }\right)\end{array}$ & 13,2 & 13,2 & 13,2 & 13,2 & 13,2 \\
\hline
\end{tabular}

$\left(^{*}\right)$ Valor mínimo destinado ds áreas institucionais referido na Lei $6.766 / 79$, art. $4^{\circ}, \S 1^{\circ}$.

(**) Área restante para uso privado em função do disposto na Lei $6.766 / 79$, art. $4^{\circ}, \S 1^{\circ}$.

(***) Valor mínimo destinado ao sistema de recreio de cada parcelamento (Lei Municipal n. 953/72).

$(* * * *)$ Estes valores foram obtidos da seguinte forma:

- pop. abs.: (7)/3 $=X \mathrm{~m}^{2} / 1.000 \mathrm{~m}^{2}+X \mathrm{~m}^{2} / 500 \mathrm{~m}^{2}+X \mathrm{~m}^{2} / 250 \mathrm{~m}^{2}=Y\left(n^{\circ}\right.$ proporcional de lotes) $Y .5 h a b=$ pop. abs. hipotéti-

ca de cada área amostral $=-$ pop. rel.: pop. abs. $/ 4 \mathrm{~km}^{2} \Rightarrow X$ hab. $/ \mathbf{k m}^{2}$ 


\section{SISTEMA VIÁRIO E PRESERVAÇÃO AMBIENTAL}

O desenho do traçado viário, especialmente em parcelamentos de pequenos lotes, com um padrão do tipo tabuleiro de xadrez ou similar, aliado a um relevo bastante movimentado, gera grandes movimentações do terreno, com muitos cortes e aterros, contribuindo para desestruturar a dinâmica geomorfológica local. Os loteamentos de chácaras têm em geral um sistema viário com ruas mais espaçadas, devido ao tamanho dos lotes normalmente superiores a $1.200 \mathrm{~m}^{2}-$, e um desenho mais orgânico, diminuindo, assim, a densidade de áreas com movimentações de terras. Apesar de o tipo de solo local ser resistente à ocorrência de erosão por ravinas e voçorocas, o relevo é muito acidentado, predispondo o solo à erosão laminar, quase imperceptível, mas que se observa em dias de chuva, quando as águas fluviais tornam-se avermelhadas pela presença de partículas de solo carreadas pelas águas pluviais. Como conseqüência, enfatizase a perda de solo e o assoreamento dos corpos d'água, comprometendo inclusive a qualidade da água para consumo, bem como a capacidade dos reservatórios d'água.

Como já levantado anteriormente, o sistema viário também ocupa muitas vezes a linha de cumeada pela facilidade do traçado, já que as declividades não são muito acentuadas e a necessidade de cortes e aterros é menor.

É prática comum nas áreas urbanas a construção de avenidas de fundo de vale, ocupando justamente as áreas de preservação permanente. A Figura 6 demonstra isso claramente com diversos trechos dos córregos que cruzam a cidade já com suas margens transformadas em avenidas. O fato é agravado pela retificação, canalização e impermeabilização dos leitos fluviais, o que contribui ainda mais para a desregulação dos processos hidrológicos. 


\section{SISTEMA DE RECREIO E ÁREAS DE PRESERVAÇÃO AMBIENTAL}

Com relação às áreas livres de uso público que cada loteamento deve ter, verifica-se que em muitos casos elas coincidem com as áreas de preservação permanente. Mesmo assim, a coincidência não é total e fica a questão: até onde é compatível uma área livre de uso público - vegetada ou não - com uma área de preservação permanente? Na primeira, admitem-se alterações na estrutura do sistema (ambiente) porque o seu uso, a sua função, entre outros, é o lazer da população, o que inclui práticas esportivas, jogos, eventos culturais ao ar livre, etc. Na segunda, tal uso/ função, se permitido, é muito restrito, já que a função básica da área é manter as condições naturais dos ecossistemas que representa, isto é, a estrutura e os processos ecológicos. E uma vez que tais áreas foram transformadas em estações ecológicas pela lei $6.938 / 81$, somente em $10 \%$ (dez por cento) de sua área, "desde que haja um plano de zoneamento aprovado, segundo se dispuser em regulamento, poderá ser autorizada a realização de pesquisas ecológicas que venham acarretar modificações no

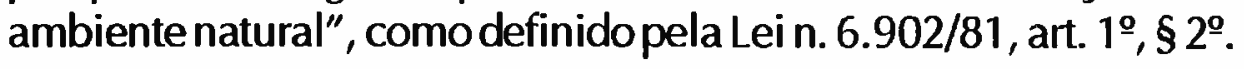

Dessa forma, as áreas de preservação permanente poderiam ser consideradas no cálculo das áreas livres de uso público? Se tomarmos o que diz a Lei n. 6.766/79, art. 3오 § único, "não será permitido o parcelamento do solo: (..) em áreas de preservação ecológica (..)" , mais o exposto acima, a resposta a essa questão deve ser não. Se as áreas de preservação permanente não são passíveis de parcelamento, além de serem estações ecológicas, e a porcentagem mínima a ser considerada como área livre de uso público recai sobre a área do parcelamento, entende-se que as primeiras não podem coincidir com as últimas. Conclui-se, portanto, que além das áreas de preservação permanente que porventura estiverem sendo englobadas pelo parcelamento, outros espaços deverão ser escolhidos para compor as áreas livres de uso público. 
Conforme pode ser verificado na Tabela 2, considerando-se as densidades populacionais para cada tamanho hipotético de lote, os índices de sistema de recreio ficam em 7,69, 15,38 e $30,77 \mathrm{~m}^{2} / \mathrm{hab}$. Com base nos dados sobre população absoluta média (15) e na área destinada a sistema de recreio (9) obtémse um índice de sistema de recreio (16) da ordem de 13,2 $\mathrm{m}^{2} / \mathrm{hab}$. Comparando-se esse índice com os valores mínimos recomendados, discriminados na Tabela 3, verifica-se que ele se apresenta próximo do recomendado, podendo-se ter pelo menos um parque de bairro e dezenas de parques de vizinhança por área amostral. Assim sendo, a população estaria com um serviço público de lazer, ao menos em termos de área, adequado às suas necessidades. Se o exercício fosse feito com base no índice de 3,88 hab./domicílio (IBGE, op. cit.), a densidade populacional absoluta e relativa seriam menores, possibilitando índices de espaços livres mais expressivos. Contudo, devem ainda ser consideradas a infra-estrutura de cada área (quantitativa e qualitativamente) e a distribuição dessas áreas pelo espaço urbano.

Em 1989, o município possuía em seu perímetro urbano sede 146 áreas destinadas ao uso público para fins de lazer, eventos culturais e afins. Dessas, somente 17 foram consideradas implantadas e com uso freqüente pela população para os fins acima mencionados. Esses valores resultaram em índices de $18,4 \mathrm{~m}^{2} / \mathrm{hab}$., considerando-se todas as áreas, e de apenas 5,1 $\mathrm{m}^{2} / \mathrm{hab}$., considerando-se somente as implantadas. Este último distribuía-se como 4,2 $\mathrm{m}^{2} / \mathrm{hab}$. de parque de bairro e $0,9 \mathrm{~m}^{2}$ de parque de vizinhança (Canno, op. cit.). Ainda assim, muitos desses espaços encontram-se em áreas de preservação permanente, o que, conforme o discutido acima, tornaria menores ainda tais índices. Evidencia-se com esses valores que não apenas as áreas de preservação permanente estão relegadas a segundo plano pelas autoridades competentes, mas também as de lazer da população. 
Tabela 3 - Caracteristicas recomendadas para os espaços livres de uso público (modificada, Geiser et al., 1975; Wright et al., 1976; e Universidade de Freiburg e Hohenheim, 1977, apud Escada, 1987)

\begin{tabular}{|l|c|c|c|}
\hline Denominação & $\begin{array}{c}\text { índice } \\
\left(\mathrm{m}^{2} / \mathrm{hab}\right)\end{array}$ & $\begin{array}{c}\text { Tamanho mínimo } \\
\left(\mathrm{m}^{2}\right)\end{array}$ & $\begin{array}{c}\text { Distância das residências } \\
\text { (raio de influência) }\end{array}$ \\
\hline $\begin{array}{l}\text { Parques de } \\
\text { vizinhança com: } \\
\text { "play-ground" } \\
\text { "play-lot" } \\
\text { "play-field" }\end{array}$ & 2,25 & $150 \mathrm{a} 800$ & $500 \mathrm{~m}$ ou $10^{\prime}$ a pé \\
\hline $\begin{array}{l}\text { Parques de } \\
\text { vizinhança com: } \\
\text { areas para esportes }\end{array}$ & 5,5 & 5.000 & $500 \mathrm{~m}$ ou $10^{\prime}$ a pé \\
\hline Parques de Bairro & 6,0 & 100.000 & $800 \mathrm{a} 1.000 \mathrm{~m}$ ou $10^{\prime}$ \\
a pé
\end{tabular}

\section{ÁREAS DE PRESERVAÇÃO PERMANENTE E O AMBIENTE URBANO}

Observa-se que as áreas de preservação permanente distribuemse por toda a área, não deixando grandes vazios nem concentrando-se num único espaço. Há, como visto anteriormente, características ambientais que privilegiam determinado uso, mas nunca de modo exclusivo. Isso possibilita uma maior manutenção do equilíbrio dos processos ecológicos, como menor desnivel de temperatura entre áreas mais e menos urbanizadas, maior facilidade nas trocas gasosas entre os diversos ambientes ao formar corredores de circulação do ar, contribuição para evitar erosão de encostas e assoreamento de corpos d'água, integração da paisagem urbana ao contexto ambiental/ paisagístico da região, manutenção da diversidade ecológica, formação de corredores naturais de troca genética entre diferentes comunidades animais e vegetais, etc. Por outro lado, e principalmente quando a área estiver inserida no ambiente urbano, a pressão sobre ela pode ser muito intensa, uma vez que se trata de usos muito distintos. Nesse ponto, considera-se ina- 
dequada a definição dessas áreas como estações ecológicas, que se configuram como uma das categorias de conservação ambiental mais restritivas ao uso antrópico. Nelas, como já mencionado anteriormente, só é possível haver alterações, e mesmo assim para fins científicos, em $10 \%$ de sua área (Lei $6.902 / 81$, art. $\left.1^{\mathbf{9}}, \S 2^{\mathbf{9}}\right)$. Num local de alta densidade populacional, como é o ambiente urbano, com diversas fontes (diretas e indiretas) de pressão transformadora do ambiente, somadas à forma com que se apresentam as áreas de preservação permanente, resultando numa superfície de contato bastante extensa, é praticamente impossível alcançarem-se os objetivos de uma estação ecológica. Cercarem-se todas as áreas de preservação permanente ou controlar-se efetivamente o seu (não) acesso é impraticável. Esse fato deve ser levado em consideração quando da realização de projetos urbanísticos.

Além disso, transformar todas essas áreas em estações ecológicas impede outros usos e atividades antrópicas compatíveis com tais áreas, usos que não comprometem sua integridade e seu principal objetivo, a conservação da estrutura e dos processos ecológicos.

Um outro fator, mas mais de caráter rural, refere-se ao fato de que muitas dessas áreas de preservação permanente se encontram em propriedades privadas. Ter-se-ia, então, estações ecológicas de caráter privado? Sendo assim, como o poder público competente atuaria nessas áreas? Este é um aspecto que a lei não observa e necessita de uma revisão.

\section{CONCLUSÕES}

Com base nos dados e na discussão dos resultados, conclui-se que a expansão urbana no município de São Roque (SP) tem se processado à revelia das condições previstas em lei, em especial a legislação ambiental. Pôde ser verificado também que a aplicação da lei, salvo no caso extremo dos topos de elevações e linhas de cumeada, produziria uma ocupação antrópica do espaço menos transformadora do ambiente e da paisagem, sem, 
contudo, impedir radicalmente os usos antrópicos (urbanos e rurais); a distribuição dos usos seria baseada não somente em critérios sócioeconômicos, mas também ambientais. Verificouse, também, que ainda restariam muitas áreas passíveis de parcelamento, possibilitando as transações imobiliárias.

Outro aspecto positivo da legislação é que ela restringe o uso exatamente em áreas mais "frágeis" em termos de processos ecológicos e menos aptas, em geral, ao uso urbano e mesmo rural. Por este ponto de vista, entende-se que a Lei 6.766/79, visando orientar as ocupações e os usos em cada área de parcelamento, é mais localizada espacialmente, enquanto que a legislação ambiental, propriamente dita, trata o espaço de uma forma mais ampla, abrangendo uma área já em escala municipal e mesmo regional.

Ainda com relação à distribuição espacial dos usos, as próprias características ambientais já condicionariam os usos em função da legislação, evitando-se casos extremos, com uma melhor integração ambiental e paisagística.

Entende-se que, com relação ao texto legal, há dois pontos que merecem uma rediscussão quanto a suas exigências. O primeiro refere-se aos limites dos topos de elevações e linhas de cumeada. Seus limites são definidos de modo muito abrangente, o que certamente produziria conflitos quando de sua aplicação. $O$ segundo trata da definição das áreas de preservação permanente como estações ecológicas. Uma definição como uma unidade de conservação menos restritiva poderia facilitar a sua implantação e sua manutenção.

Quanto às técnicas empregadas neste exercício, considera-se que os critérios de número e distribuição de amostras, bem como os dados registrados, foram adequados. $O$ único dado que não apresentou bons resultados foi o mapeamento das linhas de nível, que para a escala utilizada necessitaria de uma equidistância menor. Contudo, o que se conseguiu já foi suficiente para mostrar indícios e tendências como discutido no item 4. 
Por fim, embora os padrões previstos pela legislação sejam arbitrários e genéricos para o país como um todo, é indiscutível a necessidade e o papel que os objetos de preservação têm para a manutenção dos processos ecossistêmicos e, daí, da própria qualidade de vida humana.

\section{BIBLIOGRAFIA}

BRASIL. Leis, estatutos etc. FBCN/CESP. Legislação de conservação da natureza. 3 ed., revista e atualizada até 20/09/82. São Paulo: FBCN/ CESP, 1983. 510p.

. Constituição. Constituiçãoda República Federativa do Brasil. Brasília: Diário Oficial da União, 05/out./1988.

Decreto n. 24.643/34. Código de águas. Rio de Janeiro: Diário Oficial da União, 10/jul./1934.

. Decreto n. 89.336/84. Reservas eáreas de relevante interesse ecolbgico. Brasília: Diário Oficial da União, 31/jan./1984.

.Decreto-Lei n. 227/67. Nova redação ao Decreto-lein. 1985/ 40 (Código de Minas). Brasília: Diário Oficial da União, 28/fev./ 1967

. Lei n. 4.771/65. Novo Código Florestal. Brasília: Diário Oficial da Uniâo, 15/set./1965.

Lei n. 6.535/78. Acrescenta dispositivo ao art. $2^{\circ}$ da lei n. 4.771/65 (C6́digo Florestal). Brasilia: Diário Oficial da União, 15/jun./1978.

. Lei n. 6.766/79. Parcelamento do solo para fins urbanos. Brasília: Diário Oficial da União, 19/dez./1979.

Lei n. 6.803/80. Diretrizes básicas sobre zoneamento industrial em áreas críticas de poluição. Brasília: Diário Oficial da União, 02/jul./1980. 
Lei n. 6.902/81. Criação de estações ecologicas e áreas de proteção ambiental. Brasília: Diário Oficial da União, 27/abr./1981.

. Lei n. 6.938/81. Política nacional do meio ambiente. Brasília: Diário Oficial da União, 31/ago./1981.

. Lei n. 7.511/86. Altera dispositivos da lein. 4.771/65 (C6digo Florestal). Brasília: Diário Oficial da União, 07/jul./1986.

Lei n. 7.803/89. Altera a redação da Lei n. 4.771/65 (C6́digo Florestal) e revoga as leis n. 6.535/78 e 7.511/86. Brasília: Diário Oficial da União, 18/jul./1989.

. Resolução CONAMA n. 4/85. Define as estaçōes e reservas ecológicas em seus limites territoriais. Brasília: Diário Oficial da União, 18/set./1985 (retificado no D.O.U. de 20/jan./86).

CANNO, J. M. Abordagem integrada do sistema de espaços livres de uso público da cidade de São Roque - SP. Rio Claro: Instituto de Biociências, UNESP, 1989. 87 p.il.

CENTRO NACIONAL DE PESQUISAS AGRONÔMICAS, Levantamento de reconhecimento dos solos do Estado de SãoPaulo (Contribuição à Carta de Solos do Brasil), Boletim do Serviço Nacional de Pesquisas Agronômicas, Rio de Janeiro, n. 12, 1960.

ESCADA, M. I. S. Caracterização dos espaços livres de uso público de São José dos Campos. Rio Claro: Instituto de Biociências, UNESP, 198741 p. il.

GASPAR, Antonio F Histórico do início, fundação, construção e inauguraçāo da estrada de ferro Sorocabana; 1870-1875. São Paulo, 1930. 240 p. il.

GONÇALVES, Wantuelfer. A legislação florestal e as áreas verdes municipais. São Paulo: FAUUSP, 1991. 42 p.il.

IBGE - Fundação Instituto Brasileiro de Geografia e Estatística. Sinopse preliminar do Censo Demográfico 1991, São Paulo. Rio de Janeiro, n. 19 v.6, 1991. 235p. 
IGC. Instituto Geográfico e Cartográfico. Cartas planialtimétricas SF23-Y-C-V-2-NE-A/C e SF-23-Y-C-V-2-NO-B. Escala 1:10.000. São Paulo, 1979.

. Plano cartográfico do Estado de São Paulo; Carta de utilização da terra do Estado de São Paulo/Folha SF-23-Y-C. São Paulo: Abril S/A, 1981. esc. 1:250.000. Color.

Plano cartográfico do Estado de São Paulo; Divisão municipal e distrital do Estado de São Paulo. São Paulo: Abril S/A, 1984. esc. 1:1.000.000. (Obs.: atualizado para 1995)

MACHADO, Paulo Affonso Leme. Direito ambiental brasileiro. 2. ed. São Paulo: Revista dos Tribunais Ltda., 1.989. 478p.

SAMARTINI, R. R. São Roque SP In: FERREIRA, J. P (Orient.). Enciclopédia dos municípios brasileiros. Rio de Janeiro: FIBGE, v. 30, p. 260-264, 1958.

SANTOS, Joaquim S. São Roque de outrora. "O Democrata", São Roque, 1936-1938. (Obra reunida em livro a partir de xerox).

SÃO PAULO (Cidade). Prefeitura Municipal de São Roque. Mapas dos loteamentos. São Roque: Depto. de Planejamento. Escalas 1:500, $1: 1.000$ e $1: 2.000$.

Prefeitura Municipal de São Roque. Lei n. 953/72. Plano Diretor Físico. São Roque: Câmara Municipal, 1972.

. Lei n. 1.801/90. Leiorgânica do Município de São Roque. São Roque: O Democrata, 1990.63p.

SÃo PAULO (Estado) Constituição. Constituição do Estado de São Paulo. São Paulo: IMESP, 1989. 48p.

Secretaria da Indústria, Comércio, Ciência e Tecnologia - IPT. Mapa geologico do Estado de São Paulo. São Paulo: SICCT, 1981 (a). v.1, 126p.

Mapa geomorfológico do Estado de São Paulo. São Paulo: SICCT, 981 (b). v.1, 94p. 
Secretaria de Serviços e Obras Públicas. Atlas pluviométrico do Estado de São Paulo. São Paulo: SSOP, 1972. 83p.

SEADE. Fundação Sistema Estadual de Análise de Dados. Anuário Estatístico do Estado de São Paulo: 1992. São Paulo: SEADE, v.1. 1993. 680p.

. Projeção da população residente, por faixa etária e sexo para o município de São Roque (SP), referente a julho/1994. Dados não publicados; registro em computador. São Paulo, SEADE, 1994.

SERRANO, O. Vegetação do município de São Roque. São Roque, 1986.

SETZER, J. Atlas climático e ecológico do Estado de São Paulo. São Paulo: IMESP, 1966. 62p. 